\title{
Elucidating the Visual Language of the Venus Table in the Dresden Codex: A Visual Semiotics Approach
}

\author{
Dilucidando el lenguaje visual \\ de la Tabla de Venus del Códice de Dresde: \\ un enfoque semiótico
}

\author{
MARGARITA JuÁREZ NÁJERA \\ Departamento de Energía, Universidad Autónoma Metropolitana-Azcapotzalco, México \\ Mariana Castellanos \\ École Nationale d'Administration Publique, Montreal, Canadá
}

\begin{abstract}
AвSTRACT: The visual language of the paintings has undergone a theoretical and pragmatic process, which is different than that of textual linguistics. In this paper we propose a method of analysis based on semiotics to elucidate and compare the visual response of six paintings of the pre-Columbian Maya Dresden Codex. The Venus table was chosen because it presents a calendrical-astronomical message through a visual language that makes its interpretation complex. We consider that the visual semiotics of the Quebec School represented by Saint-Martin and Shannon's entropic comparison of the Venus table paintings may be applied to both classical and contemporary pictorial works to support the work of art historians.
\end{abstract}

KeYwords: Dresden Codex; Saint-Martin's visual language; Shannon entropy; semiotics of paintings; calendrical-astronomical meaning.

Resumen: El lenguaje visual de las pinturas ha experimentado un proceso teórico y pragmático que es diferente al de la linguiística textual. En este trabajo se propone un modo de análisis basado en el enfoque semiótico para dilucidar y comparar la respuesta visual de seis pinturas del códice maya prehispánico de Dresde. Se eligió la Tabla de Venus porque ésta presenta un mensaje calendárico-astronómico a través de un lenguaje visual que hace más compleja su interpretación. Consideramos que la semiótica visual de la escuela de Québec representada por Saint-Martin y la comparación entrópica de Shannon de las pinturas de la Tabla de Venus se pueden 
aplicar tanto a obras pictóricas clásicas como contemporáneas para que apoyen el trabajo de los historiadores de arte.

Palabras clave: Códice de Dresde; lenguaje visual de Saint-Martin; entropía de Shannon; semiótica de pinturas; significado calendárico-astronómico.

ReCEPCIÓN: 23 de abril de 2019.

ACEPTACIón: 24 de agosto de 2019.

DoI: https://doi.org/10.19130/iifl.ecm.2020.56.2.0004

\section{Use of Visual Semiotics to Analyze Images}

In 1969, a group of intellectuals (including Barthes, Benveniste, Greimas, Jakobson, Lévi-Strauss, and Sebeok) adopted semiotics as the general term for the study of systems of verbal and non-verbal signs (Nöth, 1995). In practice, according to Peirce, semiotics was often limited to the theory of non-linguistic signs and signals. By contrast, according to Saussure, semiology referred to the study of textual elements used in the linguistic tradition (Sonesson, 2016, Lecture 1: 4). Semiotics - which is used to describe materials that transmit a visual language, such as paintings or sculptures- has undergone a different theoretical and pragmatic process than that of verbal linguistics. That is, given the lack of a theory of grammar of visual language or a visual semiotics that allows for a preliminary level of description of a work of art (Greimas, 1994), semiotics schools in Paris, Lund, Prague, and Quebec have proposed a variety of modes of analysis (Sonesson, 2016).

The present study considers the tradition of the Quebec school, represented by Fernande Saint-Martin (1990), which distinguishes, defines, and classifies the basic aspects of visual language with the aim of understanding the way in which elements of an artistic work are linked to each other and form an integral work of art, through their spatial relations. The aim of this paper is to elucidate and compare the visual response of six paintings of the pre-Columbian Maya Dresden Codex (1983), called the Venus Table. This is done using a method that combines an understanding of the complexity of the calendrical-astronomical message of the paintings, the mathematical theory of communication, and the visual semiotics applied to the visual arts.

The article is organized in several sections. Firstly, a calendrical description of the Venus Table of the Dresden Codex is provided in order to present an interpretation of the pre-Columbian message. Secondly, visual semiotics for paintings according to Fernande Saint-Martin is discussed. Next, the plastic description of the codex and its Venus Table is provided. Subsequently, Saint-Martin's visual semiotic method is applied to six paintings of the Venus Table, and their entropy is evaluated (Saint-Martín, 1990). Finally, the results are presented, followed by a discussion and final comments. 


\section{Use of Communication Theory to Measure the Content of a Message}

In 1948, Claude E. Shannon first proposed a mathematical theory to define fundamental limits of communication processing in order to study quantification, storage, and communication of information. Subsequently, Shannon and Weaver (1998) expanded the scope of this theory to address how the amount of information from a source may be determined. They attempted to address this issue by defining Shannon's entropy as a measurement of how much information a message produces. Classical entropy refers to the tendency of physical systems to become increasingly less organized. It is a criterion for deciding whether or not a given process between two states may occur and under what conditions. For example, we observe that heat flows from hot bodies to cold ones, but we never observe that this process occurs spontaneously in the opposite direction (García-Colín, 1972: 58). Shannon's entropy quantifies the uncertainty of information contained in a source and is calculated as indicated in equation 1 (Shannon and Weaver, 1998: 23):

$$
H^{1}=-\sum \text { pi log pi...(1) }
$$

Although this appears complicated, let us suppose a simple example of the six paintings in the Venus Table of the Dresden Codex. There are six possible messages. The probability that the messages of the paintings are the same or different will depend on the proportion of the individual characteristics that are compared. If one calculates, in this case, the numerical value of $\mathrm{H}$ (in bits) of each Venus paintings, $\mathrm{H}$ would have its greatest value when the proportion of individual characteristics is unlikely to resemble the characteristics of the other paintings or messages. When it is very likely that no difference occurs among the messages, that is all Venus paintings are equal, the value of $\mathrm{H}$ will be smaller. The entropy value $\mathrm{H}$ allows us to compare different degrees of variety or singularity contained in an object.

\section{History of the Dresden Codex}

The Dresden Codex —or Codex Dresdensis - is a manuscript on a $3.5 \mathrm{~m}$ long foldout sheet of plant fiber paper of a species of Ficus, consisting of 39 pages that

${ }^{1}$ Where:

$\sum$ is the sum of the terms,

$p i$ is the proportion of characters or individuals that belong to the type of element $i$ in the sequence of interest in the database,

$\log$ is the logarithm of the number of options available,

$\left(m^{x}=y\right.$, it is said that $x$ is the logarithm of $y$ based on $\left.m\right)$. 
measure $20.4 \mathrm{~cm}$ high by $9.1 \mathrm{~cm}$ wide. Four pages are blank on one side and the rest are painted on both sides. It is possible that the codex formed part of the taxes that Hernan Cortes sent to Emperor Carlos V in 1519 (Coe, 1996: 90). The book was first made known in Vienna, and Johann Christian Götze - chaplain to the king of Poland and director of the Royal Library of Dresden- purchased it in 1740 (Coe, 1996: 92). In the early 1800s, Alexander Von Humboldt —upon learning about it from a book published shortly before- made the first reprint of pages 47-52. Between 1831 and 1848, the entire codex was copied by an Italian artist and reproduced by Lord Kingsborough (Thompson, 1988).

The manuscript was revealed in its entire splendor with the chromolithographic reproduction of Förstemann in 1880 (Toscano, 1984; Spinden, 1975: 152). In 1892, the second edition by Förstemann (Thompson, 1988) was printed, with the same images but with the page order corrected. In 1930, a black and white copy of the Förstemann edition was published by Villacorta and Villacorta (Thompson, 1988). In 1932, the first foldout reproduction by Gates of the Maya Society was published (Thompson, 1988: 45). Bricker and Bricker (2011) offer an exhaustive explanation of the history as well as the structure and current interpretation of the Dresdensis. Below we present pages 24 and 46 to 50 of this codex as they appear in color in the facsimile of the first Förstemann edition from 1880, ordered according to the 1892 edition. $^{2}$

\section{Calendrical Message of the Venus Tables of Dresden Codex}

We selected the Dresden Codex for analysis because its drawings are an inestimable source for studying the pictorial art of one of the pre-Columbian cultures of Mexico (Toscano, 1984: 136). Toscano (1984: 124, 125) mentions that the figures are vigorously trim, without shadows or dark colors; they have a polychrome liveliness given the absence of medium tones and presence of primary colors; they show dazzlingly beautiful colors given the absence of dull colors or shade; they express an ingenious perspective given their planographic nature and displaced profiles; and the figures reveal disproportion and a lack of reality. All of this contributes to the delicate freshness of the enigmatic glyphs. ${ }^{3}$

Within the Dresden Codex, we selected pages 24 and 46 to 50 of the Venus Table, given that according to Aveni (1979: 275) the Maya Venus cycle combines "long term precision with short term faults as a true ephemeris", that is, it portrays important happenings that occurred on a single date but in different years that generally coincide with certain domestic religious ceremonies. Furthermore,

\footnotetext{
2 This version is available at Foundation for the Advancement of Mesoamerican Studies: < http://www. famsi.org/spanish/mayawriting/codices/dresden.html $>$.

${ }^{3} \mathrm{~A}$ glyph is a sign that may appear alone or in a group of signs that occupies a defined space, or block, in a hieroglyphic text. In the Mayan texts, the blocks are usually arranged in columns that are read from left to right and then from top to bottom (Bricker and Bricker, 2011: 2).
} 
the morning star (Venus) was adored and attended to because it represented natural forces that were understood to affect earthy activities. The appearance of gods in the Venus cycle predicted the rainy season - and thus the most propitious time to plant- as well as the quantity of the resulting harvest. The content of the Dresden Codex undoubtedly belongs to the calendrical system and the computation of time; consequently, its significance is not only plastic but also mythological and calendrical-astronomical (Toscano, 1984: 136).

No pre-Columbian culture has provoked such interest, posed so many enigmas in deciphering its writing, or been so little understood regarding its obsession and precision for counting time as the Maya culture (Coe, 1996; Freidel, Schele and Parker, 2001; León-Portilla, 1994; Martin and Grube, 2002; Pallán, 2011; Proskouriakoff, 2007; Rice, 2007, Schmidt, De la Garza and Nalda, 1999; Stuart, 2011; Taladoire and Courau, 2005).

All civilizations have been interested in counting time (Aveni, 1991: 13). Measuring time involves a social encounter (Van de Ven and Poole, 2005: 1391), that responds to a need to carry out certain activities such as harvests, religious rites, or hunting; through this encounter, objectives shared by the group are harmonized. Time is measured; that is, changes that affect us through arbitrary norms or rules are determined by convention, given that without common measurements of time it would be impossible for social groups to function (Savater, 2003).

The Dresden Codex is the most studied codex of the three pre-Columbian Maya codices existing in Europe (Sotelo, 2012). It contains calendrical, astronomic, and esoteric information in the form of calendars and prophetic passages (Kettunen and Helmke, 2011: 46). Thompson (1988) grouped the contents of the codex into three categories: calendars and calculations of 354 days, including indications for adoration as well as prophecies (which occupy the majority of the book); an astronomic-astrological section (the eclipse tables and Venus Table); and prophecies for the year and the k'atun (19.7 years of 365 days each).

Figures 1 and 2 show the Venus Table, which contain three paintings per page and illustrate the general structure of the almanac of the planet Venus (Bricker and Bricker, 2011). According to Aveni (1979; 1991), Bricker and Bricker (2011), Fuls (2002), Milbrath (1999), Thompson (1988), and Wells (1991), Tables 1 and 2 show the organization of the calendrical message of the Venus Table. It communicates mathematical operations using the Maya dot-bar numerical nota$\operatorname{tion}^{4}$ and describes the functioning of the sacred 260-day calendar, the names of the days, the glyph for the cardinal directions, as well as representations of the moon, Venus, and other planets.

\footnotetext{
${ }^{4}$ In dot-bar notation, a dot means 1 , a bar 5 , and an oval (stylized shell), zero. The system is vigesimal (based on 20), and the value of the position increases in whole powers of twenty, from below to above, with one exception: the value of the third position is 360 instead of 400 ( $20 \times 20$ or $20^{2}$ ). The Maya probably made this substitution because 360 is the manipulable number that approximates the length of a solar year (Aveni, 1979: 276).
} 


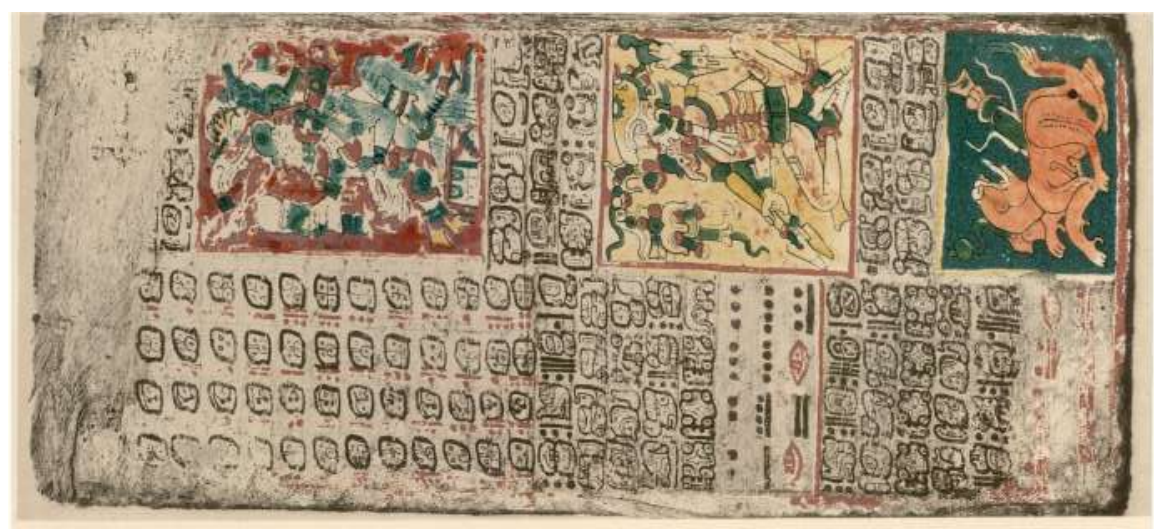

รั
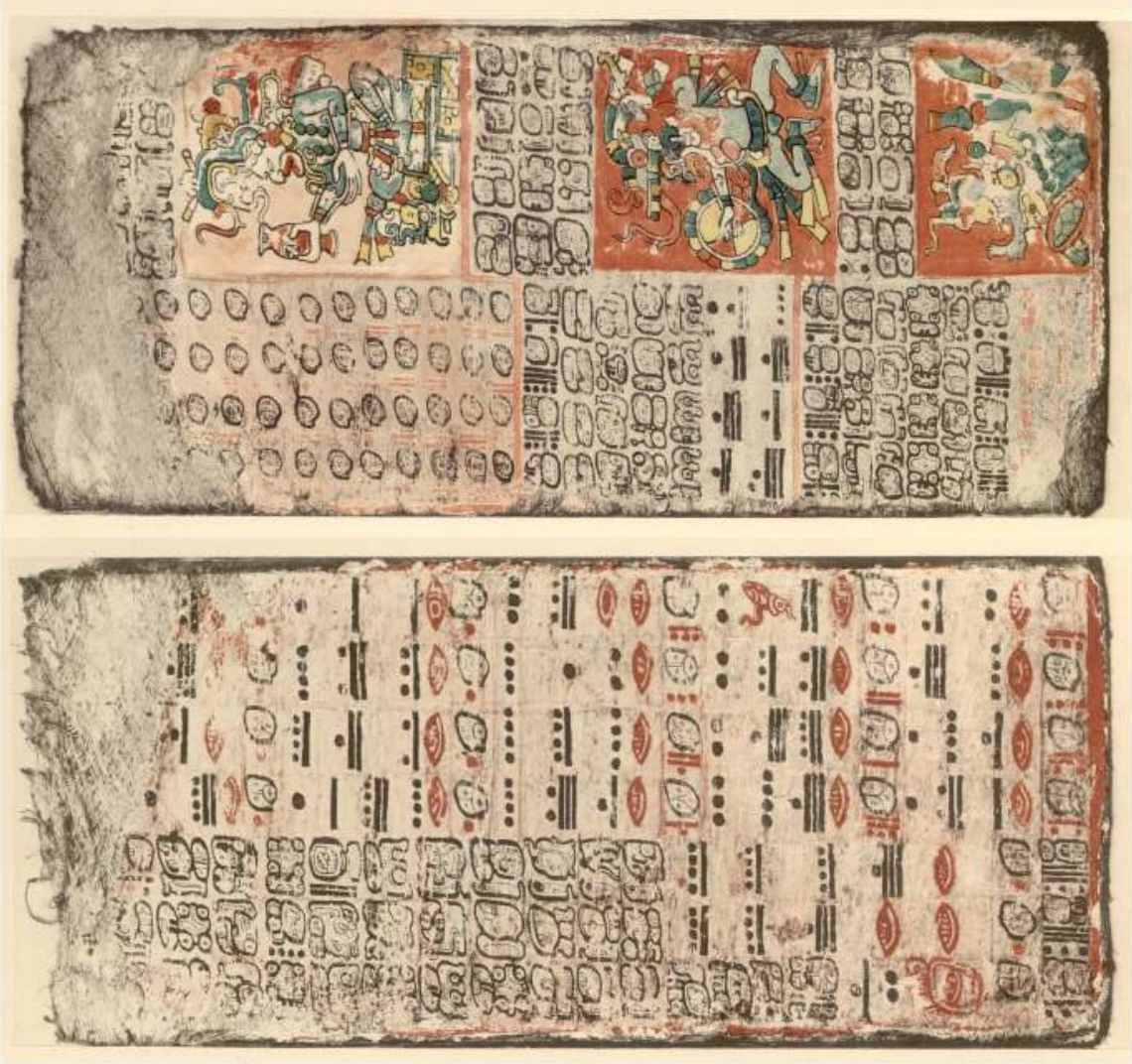

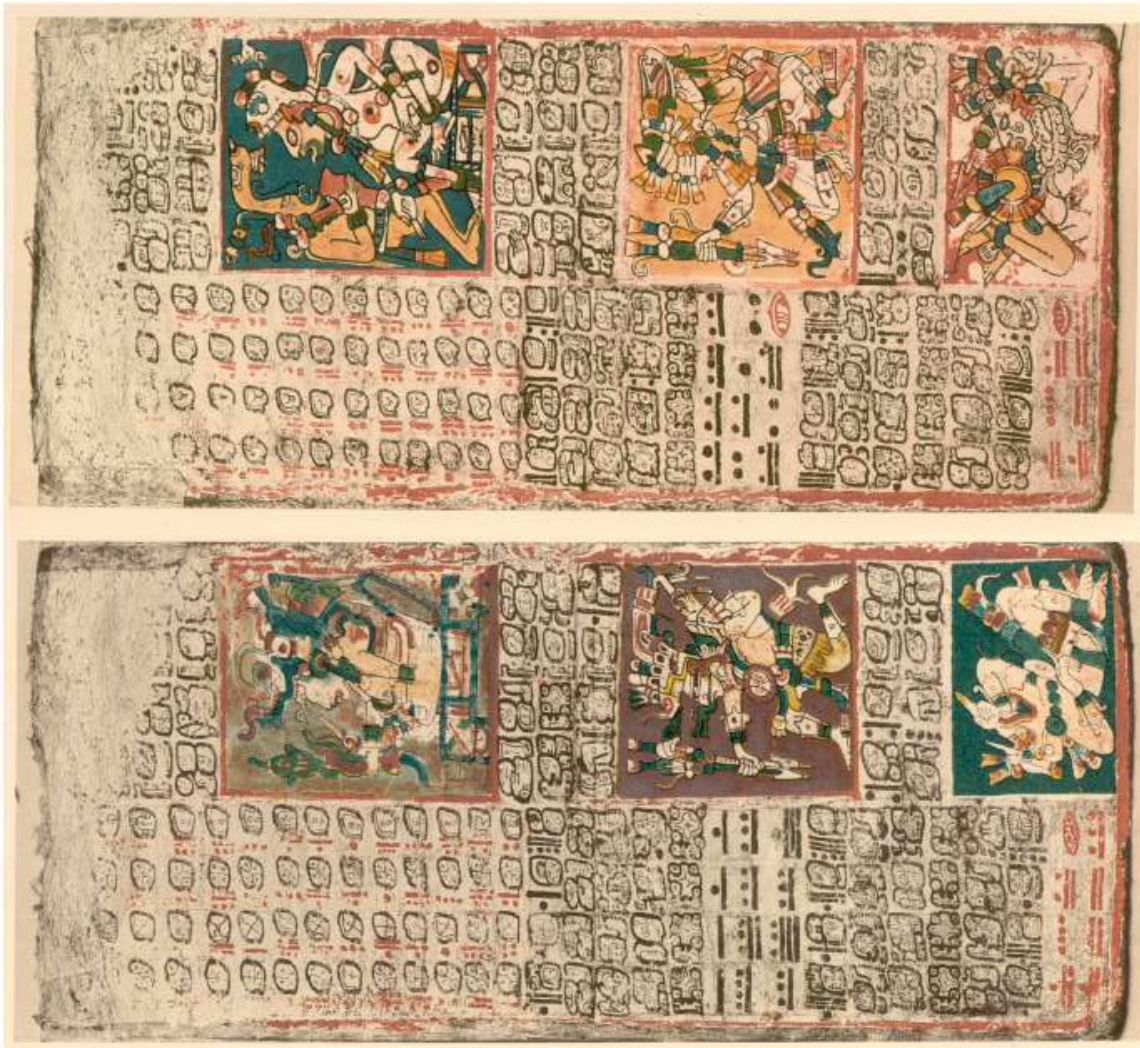

우

ฐ্ণ

(3)

कृ

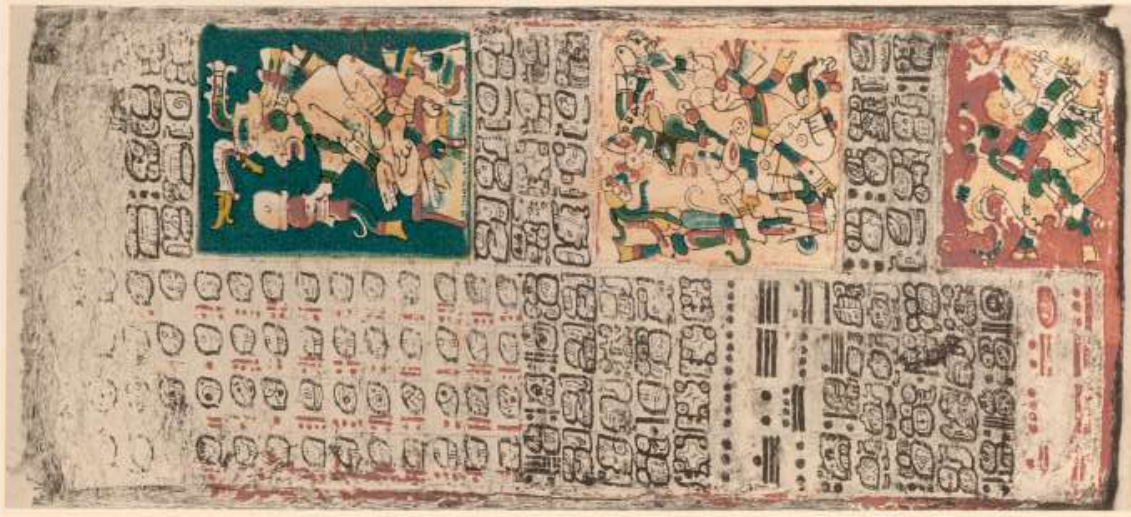


The first page (24) serves as a user's guide to the Venus Table; this guide principally consists of approximate multiples of the length of the table of 2920 days (584 days $x 5$ periods), as well as dates of initial series corresponding to the starting point in the table. The dot-bar numbers in the lower left corner in five positions (columns B and C, lines 18-24, Table 1) represent the number of days that passed from the moment of the final creation period ${ }^{5}$ to the events of Venus mentioned in the table. The 1,366,560 days since the mythic period are termed "long count" (LC), mentioned in column B (Table 1). In column C, of Table 1, the other LC number, $1,364,360$, begins 2200 days before the first; the number 2200 appears in the lower part of column A (lines 21, 22, and 24, Table 1) with a "ring" around the zero; the ring date closely approximates the appearance of Venus as the morning $\operatorname{star}(5 \times 584=2910$ days $)$ and is approximately the difference between the two long count numbers.

The LC number $(1,366,560)$ is divisible without a remainder by 260 (days of the sacred calendar, Tzolk'in), 365 (days of the civil calendar, Haab), 584 (days of the synodic ${ }^{6}$ period of Venus), 2920 (days during which Venus appears on the horizon or ortho ${ }^{7}$ ), and 37,960 (length of the Venus table). The Lc number probably was invented for the simple reason that it was commensurable with a multitude of cycles of Maya time.

The remaining pages (46-50) address the Venus ritual through a long series of important dates of the 260-day calendar (Tzolk'in dates) related to the planet, and -in the final four right-hand columns on Tables 1 and 2- drawings of the Maya ruler god, the personification of the planet Venus, and the victims of the rays of the planet Venus (from above to below). The five paintings are equivalent to five cycles of Venus or 8 Earth years.

In the first four left-hand columns (A-D) on Tables 1 and 2, in line 26, four numbers are shown (read from left to right) in dot-bar notation: 236, 90, 250, and 8 , which added together sum 584 - the closest whole number to the average synodic cycle of Venus. The number 8 (column $\mathrm{D}$, line 26, Table 1 and 2) is the most significant number of the Venus cycle, representing the period when Venus disappeared behind the sun; the other 3 numbers $(236,90$, and 250$)$ also denote the days that Venus appears or disappears behind the sun.

The longest section of the paintings consists of the first 13 lines in the upper left, in columns A-D Tables 1 and 2. Each line contains four symbols representing the start of the four seasons of Venus. Each symbol designates a day in the 260-day calendar. Each symbol consists of two components: a number from 1 to

\footnotetext{
${ }^{5}$ Studies regarding the correlation of our calendar with that of the Mayan based on historic and ceramic evidence as well as radiocarbon dating suggest that this mythological creation took place August 14, 3114 BC (Wells, 1991; Fuls, 2008).

${ }^{6}$ Synodic period: interval of time that a planet takes to return to the same point (Ferro, 1999).

${ }^{7}$ Ortho: from an observer's standpoint, a star is in the ortho when it crosses the plane of the horizon and passes to the visible hemisphere, when "it dawns", that is, when its astronomical height is zero, going from negative to positive (Ferro, 1999). "Ortho" and "Venus sunrise" are synonymous.
} 
13 , and a glyph representing the name of a day in a 20-day cycle. Given that 13 and 20 have no common factors, each day in a 260-day cycle may be individually designated in this manner. Thus, for example, on page 46 , line 8 , column $\mathrm{A}$, Table 1, the start of the appearance of Venus for 260 days as the evening star designates the day Kib with the number 7; the disappearance of Venus for 90 days designates 6 Kimi (column B); the period of the morning star designates 9 Kib (column C); and the disappearance of Venus 8 days designates 4 Kan (column D). With respect to our calendar, a comparable statement would be that Venus disappears "Wednesday, the fourth".

All lines of the Venus table are read consecutively from one page to the next. Line 1, columns A-D, of the five pages (46-50), Tables 1 and 2, represents five consecutive journeys through the 584-day cycle; line 2 represents the next five, and so forth. The length of the entire table is therefore $5 \times 13 \times 584=37,960$ days, an interval that has the special property of being divisible, with no remainder, by the 584-day period of Venus, the sacred 260-day period, and the 365-day so-called civil year.

The numbers on the left of lines 14,20 , and 25 , Tables 1 and 2, provide alternate positions of the civic year (365 days) that are equal to positions in the Tzolk'in calendar (or wheel), as seen in lines 1-13 of the appropriate column. Thus, the complete entry of the calendar wheel on page 46 , column $C$, line 14 , Table 1, would be 4 Yaxkin, 14 Zac, 19 Zec, 7 Xul.

The glyphs to the left on lines 16 and 24 of Tables 1 and 2, indicate the directions (North, West, South, East) repeated in variable order. Evidently, the successive appearances of Venus were associated with different quadrants of the horizon. The glyphs to the left on line 17 are associated with the order of "gods"; these series of glyphs that appears in numerical order (\#1, \#2, \#3...\#20). The glyphs to the left on lines 18 and 23 of the tables were identified by Förstemann (Thompson, 1988) as Venus glyphs. They are frequently associated with a sign, which is interpreted to mean "red".

On each page, the numbers to the left of line 19 of each Venus Table represent the accumulated totals obtained upon adding the number of line 26 of the same column to the number of line 19 of the previous column. Thus, on page 46, columns A-D, line 19 of Table 1 the numbers are 236, 326, 576, and 584. If 90 days are added to 236 from line 26 , column $A$, the result is 326 . This process continues throughout the 5 pages; therefore, the final accumulated quantity on page 50 is $5 \times 584=2920$.

On the right of pages 46-50, columns E-H, lines 4-12, 16-20, and 23-26 of Tables 1 and 2 is a set of images that represent the celestial occurrences that accompany the appearance of Venus as a morning star or ortho after inferior conjunction, ${ }^{8}$

\footnotetext{
${ }^{8}$ For the inner planets, which are those within Earth's orbit (i.e. Mercury and Venus), there are two conjunctions: the superior and inferior. In the superior conjunction, the planet is behind the Sun (seen from Earth); in the inferior conjunction, the planet is in front of the Sun (Ferro, 1999).
} 


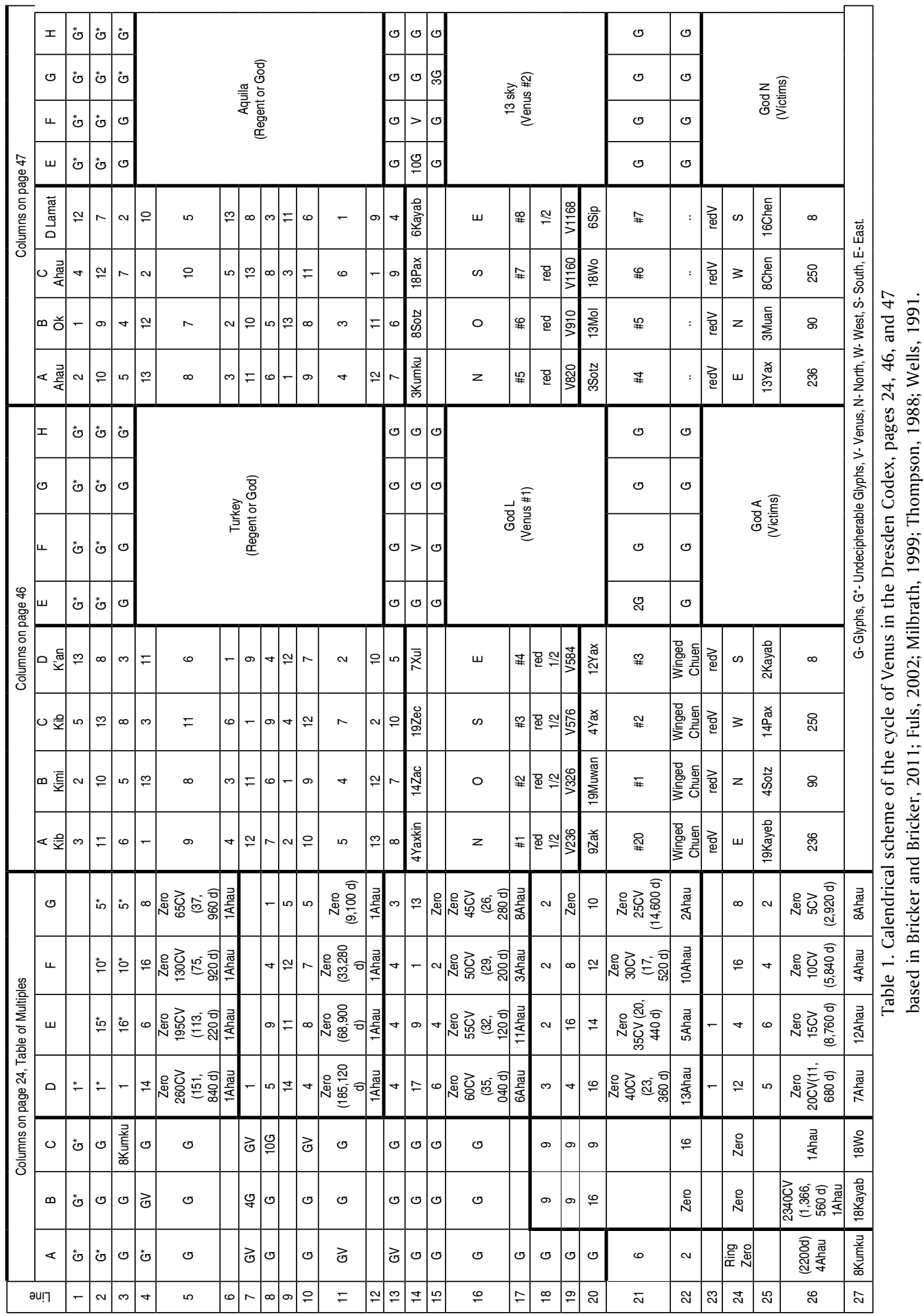




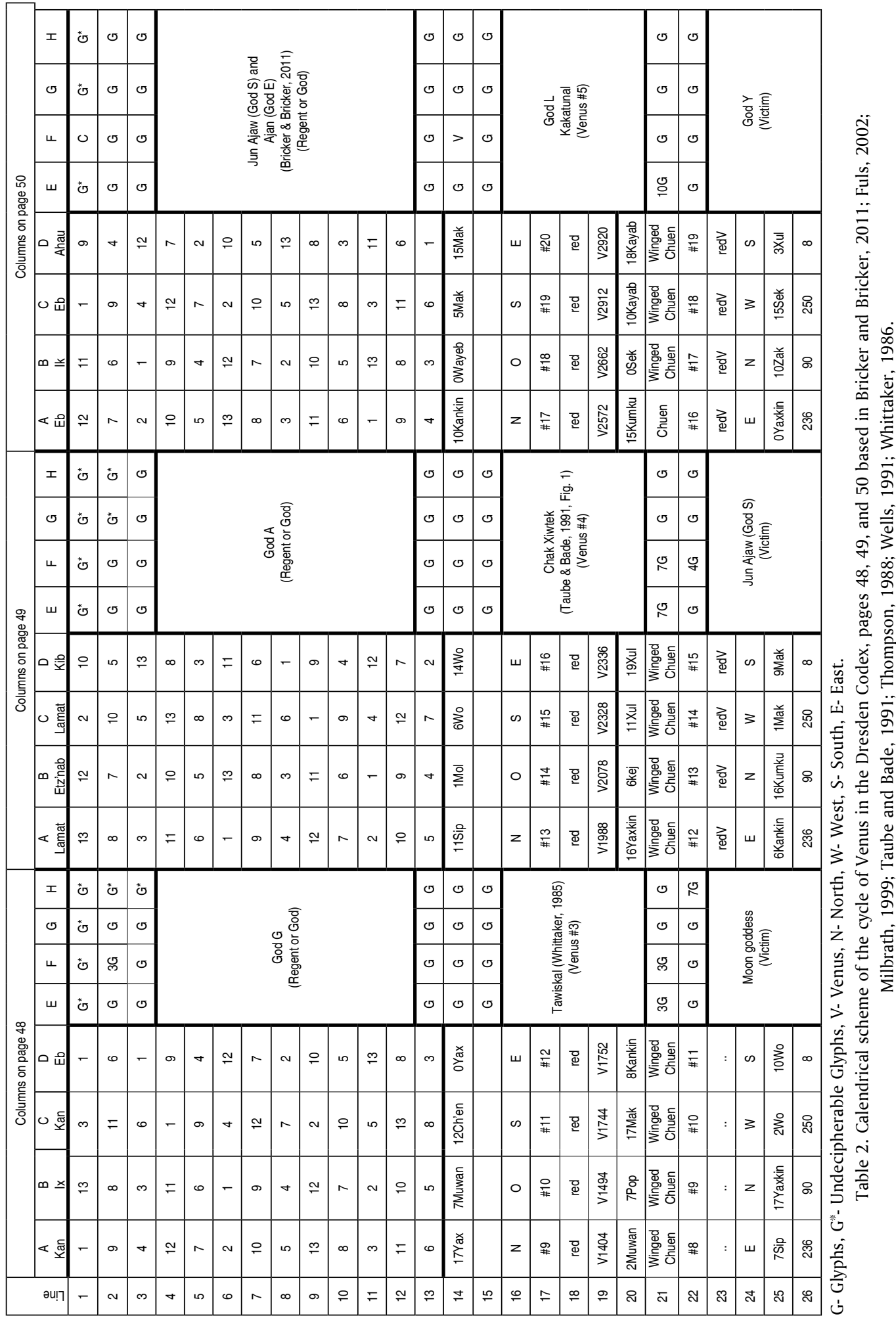


which is the reappearance of Venus after it has been blocked from human sight by the sun. Glyphic symbols are interspersed among the images and time intervals. The celestial events are presented in groups of three images on each page.

In the upper image on page 46 (Figure 1) is an old toothless god, seated on a throne, offering sacrifices to the deity Venus in honor of its appearance. The second image is an aggressive personifier of Venus, with an atlatl (dart thrower) raised for action. The third image represent the victims, and there on the following appear: deity $K$ (of fertility?) during K'an days; the jaguar (warrior) during Lamat days; the god of maize during Eb days; the frog deity (rain) during Kib days; and the god 1055 (water?) during Ahau days. In the image halfway in the middle of page 46, lines $15-20$ of Table 1 is deity L. A manifestation of the god Venus is shown with an atlatl (dart thrower) in its left hand and a shield in the other (Figure 1). Deity $\mathrm{L}$ throws the dart that represents the dazzling rays of Venus when the planet is made visible on the horizon. The lower image on the same page contains a sacrificial victim, God K, with a lance through his intestines.

\section{Description of Visual Semiotics by Fernande Saint-Martin}

\section{Plastic characteristics}

Fernande Saint-Martin (1990) proposed some basic procedures for analyzing visual language based on psycho-physical structures defined with respect to subjective as well as objective aspects of perception -in particular the structure and mechanisms of visual perception. ${ }^{9}$ This author also proposed some syntactic rules of visual language that function as regulators of visual transformations and energy more than as norms that govern relationships between discrete and stable elements.

Saint-Martin (1990: 6) defined the basic unit of visual language as a coloreme, which is any colored entity located at the termination point of an ocular fixation which contributes to the formation of a visual percept. Is the zone of the visual field responsible for the ocular gaze. Coloremes are always linked to other visual regions in an area of uninterrupted perception that distinguishes them from all other sensorial, tactile, kinesthetic, or verbal stimuli. Upon perceiving a visual text, no chromatic silences occur among coloremes.

The plastic characteristics that Saint-Martin (1990) proposes describe the color and texture of materials observed; that is, they are variables with the objective characteristics of the matter perceived in the visual field. On the other hand, subjective or perceptual characteristics describe the dimension or size of the

\footnotetext{
${ }^{9}$ Our view of the world is not only an optic figure, or a product of reflections of light; it is also intuition and visual perception that we elaborate based on experience and social practice (SaintMartin, 1990).
} 
object observed, its position in the plane, its vectoriality or orientation, and its boundaries; they produce a subjective mental process of synthesis regarding the object in the visual field that indirectly produces forms. Saint-Martin (1990: 12) considers the visual space that images create to be topological. That is, the geometric properties and spatial relationships of visual images are not affected by continual changes in the form or size of the figures.

Color

Experience shows that normal human vision is chromatic. However, no complete theory exclusively studies color (Saint-Martin, 1990; Sonneson, 2016). Visual semiotics proposes a system describing the chromatic phenomenon of color that includes 13 chromatic poles - red, blue, yellow, green, orange, violet, ochre, purple, brown, pink, white, black, and grey-, which Saint-Martin (1990: 33) holds are not naturally found in any particular order and that they are recognized and named by all humans.

Color is the product of a perceptual phenomenon that occurs in the interface of matter in contact with air. The perception of color is an objective phenomenon of ocular reaction to the stimulus of light waves of varying wavelengths. The chromatic poles have a dynamic behavior as a result of combining: 1) one`s subjective sensory perception of the colors as well as of the saturation or holistic appearance of intensity of color; 2) tonality, or production of different shades of colors that produce effects of volume and depth; 3) luminosity, or the play of lights which are perceived as vibrant, expansive, and radiant; and 4) complementarity among colors, which provides continuity, contrast, and chromatic harmony.

\section{Texture}

In general, texture refers to an endless number of sensations that may be felt or observed such as softness/hardness, concentration/dispersion, and depth/nearness, as well as frames, roughness, and uniform, brilliant, or absorbing colors. In visual semiotics, texture is understood to be a plastic variable designating a property of colored matter in its innermost depths as well as on its surface, whereby it presents various inclinations and disjunctions which modulate in different ways the absorption and refraction of luminous rays on opaque bodies, thus modifying their chromatic effects (Saint-Martin, 1990: 50).

Texture includes the surface on which a pigment is applied, as well as the way in which an object is perceived in the pictorial plane. The surface may be masked, accentuated or transformed by the composition of pigments and the manner in which these pigments are physically dispersed. However, within the forms, the tone of the pigment may vary, influencing the spatial organization of the overall field of perception. The texture may appear to be fine, medium, or course granulation, or be stretching or waving, or it may appear as frayed material. The 
pictorial plane may be described - for example — as a cloth which is stained, with a smooth and bright or a dull color or varnish, with dappled stokes or protuberances, corrugated, juxtapositioned or superimposed, speckled, or dotted.

\section{Characteristics of Perception}

\section{Dimension or size of the object observed}

Dimension refers to a dynamic visual field formed by a play of tensions involving the mass or size of the object observed, proportional to its possible expansion into neighboring fields (Saint-Martin, 1990: 237), as well as to the quantity of chromatism, ${ }^{10}$ luminosity, and texture - all of which may modify the perception of distance, proximity, continuity, or disconnection among elements in the visual field.

Position in the plane of the object observed

This perceptual characteristic refers to the relative position of groups of coloremes in the visual field with respect to the spatial dimensions of height, width, and depth. The dimension of depth allows for portraying outlines so as to create the optical effect of position in the plane (Saint-Martin, 1990: 55).

Vectoriality, or orientation of the object observed

Vectoriality refers to the orientation of the formants ${ }^{11}$ in three spatial dimensions. This produces an intentional effect of prolonged tension that affects the relationships between near and far regions within the visual field. Tension, unlike the position of the plane, consists of forces that produce movement and direction (Saint-Martin, 1990: 61).

Boundary, or outlines of the object observed

This perceptual characteristic refers to a qualitative change between two neighboring regions in the visual field, tending to produce open or closed forms. The borders mark the division among visual zones and may appear as clear or diffuse outlines due to gradual changes within an autonomous plane, or because they are juxtaposed or contrasting. As with the other variables, outline plays an important role in spatial organization and composition of the other variables (Saint-Martin, 1990: 62).

\footnotetext{
${ }^{10}$ Sensory perception of the purity and intensity of a color that distinguishes it from other colors (Saint-Martin, 1990: 237).

${ }^{11}$ Visual elements or predominant forms (Saint-Martin, 1990).
} 


\section{Visual Description of the Dresden Codex and the Venus Table}

Each page of the Codex Dresdensis has a red-painted border, except page 74, which has a black border; many pages retain only traces of this border. Most pages are divided horizontally into three sections; others have only two. In general, the sections are divided by red lines, which are absent in some arithmetical tables, perhaps due to wear.

\section{Visual characteristics}

\section{Color}

With respect to the chromatic perception of the Codex, three colors predominate: white, black and red. The background of most of the glyphic texts is white, although in some cases it is red, blue, yellow, green, ochre, brown, or grey, though the paint is worn. Over the background, in principle black and red lines are drawn, which provides spatial organization to each glyphic text, besides serving to outline each formant and glyph. When applying the watercolor pigment, figures were outlined in black or red, then other colors were used to fill in the spaces. Due to variations in tone, it is known that colored paint was prepared in small quantities to be applied with a brush over the glyphic texts. Once the color was applied, the forms were retraced with black lines to clearly define the figures and make the other colors stand out. Glyphs were given thick outlines, in contrast to the fine outlines of the figures (Salgado, 2001; Spinden, 1975: 152).

The Venus Table has a white background. Borders between pages are outlined with black and red lines, organizing the visual space according to the scheme of Figures 1 and 2. Three images appear on each page; the most notable aspects of these images are the color of the background, the details of a ceramic vessel that the regent holds, the clothing of the personification of Venus, and the orientation in which the lance cuts through the victims. All figures are observed from a profile, outlined in black. On page 46, the upper image has an ochre background, and the middle and bottom a red background. On page 47 , the background of the upper image is red, the middle ochre, and the bottom blue, while on page 48 the order of the colors is reversed. On page 49, the background of the upper image is ochre, the middle red, and the bottom blue. Finally, on page 50, the background of the upper image is blue and the middle and bottom ochre.

\section{Texture}

The scribes of the Dresden Codex prepared the rough ficus paper by painting a first coat with powdered limestone so as to create a homogenous white surface. The brushstrokes left no lines; rather, the paint layers are uniform, through over time they have worn away. Powdered pigments were applied to small areas at a time. More than evoking the subject represented, the textures of the codex 
invite the observer to perceive -in miniature - round, dense spaces, perhaps mottled to a novice eye (Salgado, 2001).

The texture of Figures 1 and 2 of pages 24 and 46-50 of the Venus Table causes the same sensation, as does the rest of the codex, with its homogenous white surface. The white color of the four columns on the right side of page 24 is less saturated than that of the other pages; the glyphs of the middle and bottom lines of pages 46-50 refer to the top half of the first three columns to the left of page 24 , which has similar glyphs, all of which are highly saturated with black. Pages 46-50 are surprisingly homogenous; the spaces are divided in the same proportions and are thus the same size, as seen in Figures 1 and 2.

\section{Characteristics of perception}

\section{Dimension}

Each of the 39 pages in the Codex Dresdensis is $20.5 \mathrm{~cm}$ high by $9 \mathrm{~cm}$ wide, and the entire codex is $350 \mathrm{~cm}$ long (Salgado, 2001). There appears to be a movement within the visual field of the images on pages 46-50 due to the varying lengths of the images; while the upper images - those of the regents- measure $5 \mathrm{~cm} \times 4.5 \mathrm{~cm}$, those of the personification of Venus are $4.5 \mathrm{~cm} \times 4.5 \mathrm{~cm}$, and those of the victims (in the lower right) are $3.4 \mathrm{~cm} \times 4.5 \mathrm{~cm}$. The lower image on page 50 is only $3 \mathrm{~cm} \times 4.5 \mathrm{~cm}$, but the difference between this image and those mentioned above is not apparent because the light-colored background makes the image appear as wide as the rest. One has the sensation of movement of the images from above to below, although the pages in the upper part of the calendar (lines 1-13, Figure 1) are read from left to right. In the middle of the Venus Table, in dot-bar notation the movement goes from below toward the middle in order to carry out the arithmetical operations, and in the section of the predictions, the reader is referred to the images of the victims (below) and the regent (above).

\section{Position}

In some ancient paintings (Egyptian, Persian, Byzantine, pre-Hispanic), the background lacks depth, existing only as an inert receptacle upon which objects float. In the case of the Codex Dresdensis -including the Venus Table-, it lacks depth.

\section{Vectoriality}

The formants of the glyphic texts are typically presented with the vertical axis oriented predominantly upward combined with glyphic text located horizontally. The slanted position of some of the anthropomorphic figures in the codex, as well as their position, gives the appearance of movement. The formants are composite or combined forms that together are somewhat symmetrical; some are viewed from a profile and others from the front. The formants carry objects, and 
the formants and objects act as forces pushing against each other, providing an effect of energy and tension (Salgado, 2001).

In the images of the Venus Table, the regents or gods on pages 46-49 (upper image) are seated and seen from a profile, with a ceramic object in their right hand. They do not show movement, although one regent on page 50 is clearly conversing with another person. The personification of Venus (middle image) on these five pages gives the impression that it is moving; its feet denote action and its right arm is about to lance darts downward, while its left arm brandishes a shield which gives it stability. The victims (lower images) have apparently been knocked down, as they are lying on the ground, pierced with a dart or lance, their faces turned upward or sideways, awaiting the final blow.

\section{Border}

The visual forms are stylized with curved lines, creating an effect of movement. The formants produce a static or stable sensation, while the scene as a whole provides a sensation of rolling or movement. The lines of the figures provide dynamic visual effects of sinuous movement. The sinuous forms create a sense of tension, like soap bubbles and water in a full container. The borders of the formants are drawn as closed units that revolve around each figure in a complete, unitary, finite manner. Over the background, black and red lines provide spatial organization to each glyphic text, besides acting as the border of each formant and glyph. The majority of the formants and glyphs are outlined in black, although some numeric signs, outlines, and frames are red (Salgado, 2001).

The borders of the Venus Table are represented by glyphic texts as separate, closed, complete, finite units. All the glyphs are painted in black, as are the numbers in dot-bar notation, except zero (stylized shell and ring) and the numbers representing the four seasons of Venus (lines 26, columns A-D of all pages) that always appear in red.

\section{Application of Saint-Martin's Visual Semiotic Method}

Below, we describe the method used to analyze the Venus Table according to Saint-Martin's visual semiotics approach. We describe the 11 steps that we followed with the aim that other studies may use the same approach to analyze other pictorial works.

\section{Step 1. Obtaining an original sized copy of the work}

We made an original sized color photocopy $(20.5 \mathrm{~cm}$ high by $9 \mathrm{~cm}$ wide) of the six pages of the Venus Table based on a facsimile of the codex (Códice de Dresde, 1983). 
Step 2. Tracing or delimiting the form of the pictorial work

Over the photocopies, we delimited the forms of the Venus Table, as well as the internal limits of their content, according to the perception of the user's short term memory - for several seconds - of the effect resulting from the visual tension produced by the coloremes, that is, the flash that a glance of the eye may discern. The zone of a vertical visualization in which the eye appears to concentrate on this work measures approximately four centimeters, and the zone of a horizontal visualization measures three centimeters. Figure 3 is an example of the visual limits or coloremes of page 24 of the Venus Table.

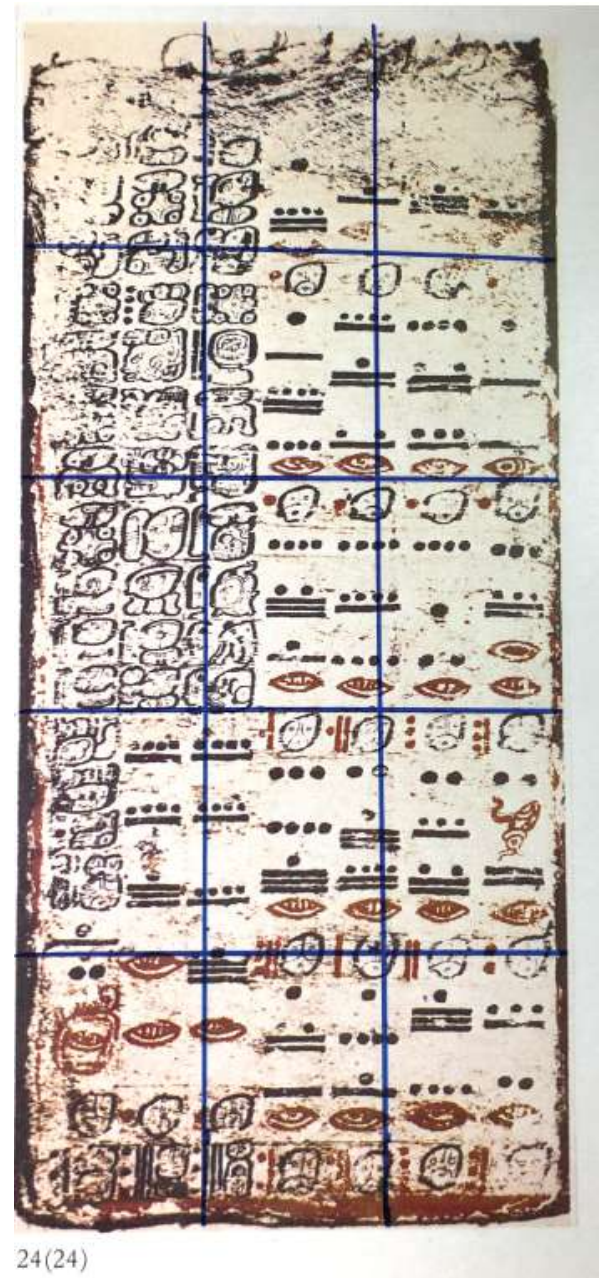

Figure 3. Vertical and horizontal delimitation of a page of the Venus Table (Códice de Dresde, 1983: 24). 
Step 3. Creating a grid over the selected work

Once the zones of visualization or coloremes were delimited, we prepared a grid on a transparent sheet the original size of the Venus Table, divided into three columns measuring $3 \mathrm{~cm}$ each vertically and four rows measuring $4 \mathrm{~cm}$ each horizontally. The size of the grid determines the number of coloremes that will be examined in each Venus table $(3 \times 4=12)$.

Step 4. Delimiting the coloreme regions

Within each coloreme, five regions were delimited according to the method of Saint-Martin in order to characterize and circumscribe five zones of visualization; the four outer zones are numbered 1 to 4 , clockwise, and the central zone is numbered 5 . Figure 4 shows the distribution of the grid, as well as the 12 coloremes in alphabetical order $(\mathrm{A}, \mathrm{B}, \ldots, \mathrm{K}, \mathrm{L})$ from left to right and above to below, numbering their five visual zones ( 1 to 5 ).

\begin{tabular}{|lll|lll|lll|}
\hline $\mathrm{A}$ & 1 & & $\mathrm{~B}$ & 1 & & $\mathrm{C}$ & 1 & \\
4 & 5 & 2 & 4 & 5 & 2 & 4 & 5 & 2 \\
& 3 & & & 3 & & & 3 & \\
\hline $\mathrm{D}$ & 1 & & $\mathrm{E}$ & 1 & & $\mathrm{~F}$ & 1 & \\
4 & 5 & 2 & 4 & 5 & 2 & 4 & 5 & 2 \\
& 3 & & & 3 & & & 3 & \\
\hline $\mathrm{G}$ & 1 & & $\mathrm{H}$ & 1 & & $\mathrm{I}$ & 1 & \\
4 & 5 & 2 & 4 & 5 & 2 & 4 & 5 & 2 \\
& 3 & & & 3 & & & 3 & \\
\hline $\mathrm{J}$ & 1 & & $\mathrm{~K}$ & 1 & & $\mathrm{~L}$ & 1 & \\
4 & 5 & 2 & 4 & 5 & 2 & 4 & 5 & 2 \\
& 3 & & & 3 & & & 3 & \\
\hline
\end{tabular}

Figure 4. Grid for analyzing coloremes and visual zones within each Venus Table.

Step 5. Locating the effect of ocular fixation in visual regions 1 to 5 within each coloreme

Zones 1 to 5 correspond to localization of the effect of ocular fixation by diverse observers that might be looking simultaneously at a coloreme, such that they allow for comparing the responses of these observers to the process of perception and their peripheral and foveal gaze. 
Step 6. Identifying the dynamic relationship among coloreme regions

Observers should consider that a dynamic relationship exists between the visual zones of each coloreme and the other coloremes that surround it, given that they are related. This influences perception of the coloremes. For example, in coloreme A, A1 has a dynamic relationship with A4, A5, A2, and B1. The same pattern is true for the other coloremes: for example, $A 2$ has a relationship with A1, A5, A3, B4, B1, and B3; H1 with H4, H5, H2, E3, G1, I1, I3, and D3, and thus onward to coloreme L, as may be observed in Figure 4.

Step 7. Selecting the semiotic characteristics for this study

This study analyzed 60 coloremes for each image of the Venus Table (12 coloremes x 5 visual zones), which are regularly spaced throughout the pictorial plane, as determined in step 4. Each of the 300 coloremes of the five paintings of the Venus Table (60 coloremes $x 5$ tables) was analyzed with respect the 6 categories mentioned above in the description of visual semiotics according to Saint-Martin (1990), that is visual and perceptual characteristics, for a total of 15 possible semiotic characteristics. This generated 4,500 records (300 coloremes $\mathrm{x}$ 15 semiotic characteristics):

Visual semiotic characteristics

1) Chromatic phenomena of color:

(a1) saturation or appearance of intensity of color as the integral presentation of color, termed solid color.

(a2) tonality or production of different shades of colors that produce an effect of volume and depth, such as use of clear colors, termed light color.

(a3) luminosity or play of lights, perceived as vibrant, expansive, radiant colors, termed vibrant color.

2) Texture or surface where the object is perceived in the pictorial plane:

(b1) of the support of the paining, termed fine granulation.

(b2) of the pictorial plane, termed worn material.

(b3) of the pictorial plane, termed brushstrokes.

Perceptual semiotic characteristics

3) Dimension or size of the object observed:

(c1) perception of distance of the object observed, termed nearness.

(c2) general division of the pictorial plane, termed horizontal division of the plane.

4) Relative position of the group of coloremes in the visual field:

(d1) depth in the pictorial plane, termed lack of depth. 
(d2) proportion in the pictorial plane, termed proportions of positions.

5) Vectoriality or orientation of the object observed:

(e1) orientation of the object observed within the three spatial dimensions, termed vertical axis of location.

(e2) orientation of the object observed, termed symmetry.

(e3) effect of movement of the object observed.

6) Outline or division among neighboring visual regions:

(f1) borders of the object observed, termed closed form.

(f2) distinct borders, termed outlines.

Step 8. Generating a matrix of frequency of appearance of the 15 semiotic characteristics in each coloreme region per Venus Table

The grid prepared in Step 3 was placed above each painting of the Venus Table to carry out a coloreme analysis according to Steps 4 through 7 . We also prepared an Excel table with the 15 visual and perceptual characteristics in columns, and the 12 coloreme regions in rows (A1 to L5) in order to record the frequency of appearance of the visual and perceptual characteristics in each coloreme region for each page of the Venus table. Frequency was recorded according to one of three values: one indicating that the characteristic was present, zero indicating that it was not present, and 0.5 indicating that it was partially present. The last row presents the sum of each column. Table 3 shows the matrix of frequency of appearance of the semiotic characteristics of page 24 of the Dresden Codex.

Step 9. Transforming frequencies into probabilities to obtain a stochastic matrix

We transformed the frequencies of appearance of each of the visual characteristics $(\mathrm{a} 1, \mathrm{a} 2, \mathrm{a} 3, \ldots \mathrm{f} 1, \mathrm{f} 2)$ in each coloreme $(\mathrm{A} 1, \mathrm{~A} 2, \ldots, \mathrm{L} 5)$ of Table 3 into probabilities by dividing the value of each cell by its corresponding sum (last row) in order to generate a stochastic matrix. The sum of the fractions or probabilities of each column (visual and perceptual characteristic) of the stochastic matrix should be equal to one. Table 4 shows transformation of the frequencies of appearance of the semiotic characteristics of page 24 of the Venus table into probabilities, generating a stochastic matrix.

Step 10. Applying the equation for Shannon entropy to each cell of the stochastic matrix

We applied equation 1 in order to determine Shannon's $\mathrm{H}$ entropy for each coloreme and visual and perceptual variable of the stochastic matrix for each of the paintings of the Venus Table of the codex. The value in each cell of the Excel table proves negative when values other than zero occur; the final values prove 


\begin{tabular}{|c|c|c|c|c|c|c|c|c|c|c|c|c|c|c|c|}
\hline \multirow[b]{2}{*}{ coloreme } & \multicolumn{3}{|c|}{ Plastic Characteristics } & \multirow[b]{2}{*}{ b1 } & \multirow[b]{2}{*}{ b2 } & \multirow[b]{2}{*}{ b3 } & \multirow[b]{2}{*}{$\mathrm{c1}$} & \multirow[b]{2}{*}{$c 2$} & \multirow[b]{2}{*}{$d 1$} & \multirow[b]{2}{*}{ d2 } & \multirow[b]{2}{*}{ e1 } & & & & \\
\hline & a1 & a2 & a3 & & & & & & & & & $e 2$ & e3 & $\mathrm{f1}$ & f2 \\
\hline A1 & 0.00 & 1.00 & 0.00 & 0.00 & 1.00 & 0.00 & 0.00 & 0.00 & 1.00 & 0.00 & 0.00 & 0.00 & 0.00 & 0.00 & 1.00 \\
\hline$A 2$ & 1.00 & 1.00 & 0.00 & 0.50 & 0.50 & 1.00 & 0.50 & 1.00 & 1.00 & 1.00 & 1.00 & 0.00 & 0.00 & 100 & 0.00 \\
\hline A3 & 1.00 & 1.00 & 0.00 & 1.00 & 0.00 & 1.00 & 1.00 & 1.00 & 1.00 & 0.00 & 1.00 & 0.00 & 0.00 & 1.00 & 0.00 \\
\hline A4 & 0.00 & 1.00 & 0.00 & 0.00 & 1.00 & 0.00 & 0.00 & 0.00 & 1.00 & 0.00 & 0.00 & 0.00 & 0.00 & 0.00 & 1.00 \\
\hline A5 & 1.00 & 1.00 & 0.00 & 0.50 & 0.50 & 1.00 & 1.00 & 1.00 & 1.00 & 1.00 & 1.00 & 0.00 & 0.00 & 1.00 & 0.00 \\
\hline B1 & 0.00 & 1.00 & 0.00 & 0.00 & 1.00 & 0.00 & 0.00 & 0.00 & 1.00 & 0.00 & 0.00 & 0.00 & 0.00 & 0.00 & 0.00 \\
\hline 82 & 0.50 & 0.50 & 0.00 & 0.50 & 0.50 & 0.50 & 0.50 & 0.50 & 1.00 & 0.50 & 0.50 & 0.00 & 0.00 & 0.50 & 0.00 \\
\hline B3 & 1.00 & 1.00 & 0.00 & 1.00 & 0.00 & 1.00 & 1.00 & 1.00 & 1.00 & 1.00 & 1.00 & 0.00 & 0.00 & 1.00 & 0.00 \\
\hline$B 4$ & 0.50 & 0.50 & 0.00 & 0.50 & 0.50 & 0.50 & 0.50 & 0.50 & 1.00 & 0.50 & 0.50 & 0.00 & 0.00 & 0.50 & 0.00 \\
\hline B5 & 0.50 & 0.50 & 0.00 & 0.50 & 0.50 & 0.50 & 0.50 & 0.50 & 1.00 & 0.50 & 0.50 & 0.00 & 0.00 & 0.50 & 0.00 \\
\hline C1 & 0.00 & 0.00 & 0.00 & 0.00 & 1.00 & 0.00 & 0.00 & 0,00 & 1.00 & 0.00 & 0.00 & 0.00 & 0.00 & 0.00 & 0.00 \\
\hline C & 0.25 & 0.25 & 0.00 & 0.25 & 0.50 & 0.50 & 0.50 & 0.50 & 1.00 & 0.50 & 0.50 & 0.00 & 0.00 & 0.50 & 1.00 \\
\hline $\mathrm{C} 3$ & 1.00 & 1.00 & 0.00 & 1.00 & 0.00 & 1.00 & 1.00 & 1.00 & 1.00 & 1.00 & 1.00 & 0.00 & 0.00 & 1.00 & 0.00 \\
\hline$C 4$ & 0.50 & 0.50 & 0.00 & 0.50 & 0.50 & 0.50 & 0.50 & 0.50 & 1.00 & 0.50 & 0.50 & 0.00 & 0.00 & 0.50 & 0.00 \\
\hline cs & 0.50 & 0.50 & 0.00 & 0.50 & 0.50 & 0.50 & 0.50 & 0.50 & 1.00 & 0.50 & 0.50 & 0.00 & 0.00 & 0.50 & 0.00 \\
\hline DI & 1.00 & 1.00 & 0.00 & 1.00 & 0.00 & 1.00 & $1 . \infty$ & 1.00 & 1.00 & 1.00 & 1.00 & 0.00 & 0.00 & 100 & 0.00 \\
\hline D2 & 1.00 & 1.00 & 0.00 & 1.00 & 0.00 & 1.00 & 1.00 & 1.00 & 1.00 & 1.00 & 1.00 & 0.00 & 0.00 & 1.00 & 0.00 \\
\hline D3 & 1.00 & 2.00 & 0.00 & 1.00 & 0.00 & 2.00 & $1 . \infty$ & 1.00 & 1.00 & 1.00 & 1.00 & 0.00 & 0.00 & 1.00 & 0.00 \\
\hline D4 & 1.00 & 1.00 & 0.00 & 1.00 & 0.00 & 1.00 & 1.00 & 1.00 & 100 & 1.00 & 1.00 & 0.00 & 0.00 & 1.00 & 1.00 \\
\hline D5 & 1.00 & 1.00 & 0.00 & 1.00 & 0.00 & 1.00 & 1.00 & 1.00 & 1.00 & 1.00 & 1.00 & 0.00 & 0.00 & 1.00 & 0.00 \\
\hline E1 & 1.00 & 1.00 & 0.00 & 1.00 & 0.00 & 1.00 & 1.00 & 1.00 & 1.00 & 1.00 & 1.00 & 0.00 & 0.00 & 1.00 & 0.00 \\
\hline E2 & 1.00 & 1.00 & 0.00 & 1.00 & 0.00 & 1.00 & 1.00 & 1.00 & 1.00 & 1.00 & 1.00 & 0.00 & 0.00 & 100 & 0.00 \\
\hline E3 & 1.00 & 1.00 & 0.00 & 1.00 & 0.00 & 1.00 & 1.00 & 1.00 & 1.00 & 1.00 & 1.00 & 0.00 & 0.00 & 1.00 & 0.00 \\
\hline E4 & 1.00 & 1.00 & 0.00 & 1.00 & 0.00 & 1.00 & 1.00 & 1.00 & 1.00 & 1.00 & 1.00 & 0.00 & 0.00 & 1.00 & 0.00 \\
\hline ES & 1.00 & 1.00 & 0.00 & 1.00 & 0.00 & 1.00 & 100 & 1.00 & 1.00 & 1.00 & 1.00 & 0.00 & 0.00 & 1.00 & 0.00 \\
\hline F1 & 1.00 & 1.00 & 0.00 & 1.00 & 0.00 & 1.00 & 1.00 & 1.00 & 1.00 & 1.00 & 1.00 & 0.00 & 0.00 & 1.00 & 0.00 \\
\hline$F 2$ & 1.00 & 1.00 & 0.00 & 1.00 & 0.00 & 1.00 & 1.00 & 1.00 & 1.00 & 1.00 & 1.00 & 0.00 & 0.00 & 1.00 & 1.00 \\
\hline F3 & 1.00 & 1.00 & 0.00 & 1.00 & 0.00 & 1.00 & 1.00 & 1.00 & 1.00 & 1.00 & 1.00 & 0.00 & 0.00 & 1.00 & 0.00 \\
\hline F4 & 1.00 & 1.00 & 0.00 & 1.00 & 0.00 & 1.00 & 1.00 & 1.00 & 1.00 & 1.00 & 1.00 & 0.00 & 0.00 & 1.00 & 0.00 \\
\hline F5 & 1.00 & 1.00 & 0.00 & 1.00 & 0.00 & 100 & 1.00 & 1.00 & 1.00 & 1.00 & 1.00 & 0.00 & 0.00 & 1.00 & 0.00 \\
\hline G1 & 1.00 & 1.00 & 0.00 & 1.00 & 0.00 & 1.00 & 1.00 & 1,00 & 1.00 & 1.00 & 1.00 & 0.00 & 0.00 & 1.00 & 0.00 \\
\hline G2 & 1.00 & 1.00 & 0.00 & 1.00 & 0.00 & 1.00 & 1.00 & 1.00 & 1.00 & 1.00 & 1.00 & 0.00 & 0.00 & 1.00 & 0.00 \\
\hline 63 & 1.00 & 1.00 & 0.00 & 1.00 & 0.00 & 100 & 1.00 & 1.00 & 1.00 & 1.00 & 1.00 & 0.00 & 0.00 & 1.00 & 1.00 \\
\hline 64 & 1.00 & 1.00 & 0.00 & 1.00 & 0.00 & 100 & 1.00 & 1.00 & 1.00 & 1.00 & 1.00 & 0.00 & 0.00 & 1.00 & 0.00 \\
\hline GS & 1.00 & 1.00 & 0.00 & 1.00 & 0.00 & 1.00 & 1.00 & 1.00 & 1.00 & 1.00 & 1.00 & 0.00 & 0.00 & 1.00 & 0.00 \\
\hline $\mathrm{H} 1$ & 1.00 & 1.00 & 0.00 & 1.00 & 0.00 & 1.00 & 1.00 & 1.00 & 1.00 & 1.00 & 1.00 & 0.00 & 0.00 & 1.00 & 0.00 \\
\hline $\mathrm{H} 2$ & 1.00 & 1.00 & 0.00 & 1.00 & 0.00 & 1.00 & 1.00 & 1.00 & 1.00 & 1.00 & 1.00 & 0.00 & 0.00 & 1.00 & 0.00 \\
\hline $\mathrm{H3}$ & 1.00 & 1.00 & 0.00 & 1.00 & 0.00 & 1.00 & 1.00 & 1.00 & 1.00 & 1.00 & 1.00 & 0.00 & 0.00 & 1.00 & 0.00 \\
\hline $\mathrm{H} 4$ & 1.00 & 1.00 & 0.00 & 1.00 & 0.00 & 1.00 & 1.00 & 1.00 & 1.00 & 1.00 & 1.00 & 0.00 & 0.00 & 1.00 & 0.00 \\
\hline HS & 1.00 & 1.00 & 0.00 & 1.00 & 0.00 & 1.00 & 1.00 & 1.00 & 1.00 & 1.00 & 1.00 & 0.00 & 0.00 & 1.00 & 0.00 \\
\hline 11 & 1.00 & 1.00 & 0.00 & 1.00 & 0.00 & 1.00 & 1.00 & 1.00 & 1.00 & 1.00 & 1.00 & 0.00 & 0.00 & 1.00 & 0.00 \\
\hline 12 & 1.00 & 1.00 & 0.00 & 1.00 & 0.00 & 100 & 1.00 & 1.00 & 1.00 & 1.00 & 1.00 & 0.00 & 0.00 & 1.00 & 1.00 \\
\hline 13 & 1.00 & 1.00 & 0.00 & 1.00 & 0.00 & 100 & 1.00 & 1.00 & 1.00 & 1.00 & 1.00 & 0.00 & 0.00 & 1.00 & 0.00 \\
\hline 14 & 1.00 & 1.00 & 0.00 & 1.00 & 0.00 & 1.00 & 1.00 & 1.00 & 1.00 & 1.00 & 1.00 & 0.00 & 0.00 & 1.00 & 0.00 \\
\hline 15 & 1.00 & 1.00 & 0.00 & 1.00 & 0.00 & 1.00 & 1.00 & 1.00 & 1.00 & 1.00 & 1.00 & 0.00 & 0.00 & 1.00 & 0.00 \\
\hline II & 1.00 & 1.00 & 0.00 & 1.00 & 0.00 & 1.00 & 1.00 & 1.00 & 1.00 & 1.00 & 1.00 & 0.00 & 0.00 & 1.00 & 0.00 \\
\hline 12 & 1.00 & 1.00 & 0.00 & 1.00 & 0.00 & 100 & 1.00 & 1.00 & 1.00 & 1.00 & 1.00 & 0.00 & 0.00 & 1.00 & 0.00 \\
\hline 13 & 1.00 & 1.00 & 0.00 & 1.00 & 0.00 & 1.00 & 1.00 & 1.00 & 1.00 & 1.00 & 1.00 & 0.00 & 0.00 & 1.00 & 0.00 \\
\hline 14 & 1.00 & 1.00 & 0.00 & 1.00 & 0.00 & 1.00 & 1.00 & 1.00 & 1.00 & 1.00 & 1.00 & 0,00 & 0.00 & 1.00 & 1.00 \\
\hline 15 & 1.00 & 1.00 & 0.00 & 1.00 & 0.00 & 1.00 & 1.00 & 2.00 & 1.00 & 1.00 & 1.00 & 0.00 & 0.00 & 1.00 & 0.00 \\
\hline $\mathrm{K} 1$ & 1.00 & 1.00 & 0.00 & 1.00 & 0.00 & 1.00 & 1.00 & 1.00 & 1.00 & 1.00 & 1.00 & 0.00 & 0.00 & 1.00 & 0.00 \\
\hline$K_{2}$ & 1.00 & 1.00 & 0.00 & 1.00 & 0.00 & 1.00 & 1.00 & 1.00 & 1.00 & 1.00 & 1.00 & 0.00 & 0.00 & 1.00 & 0.00 \\
\hline $\mathrm{K} 3$ & 1.00 & 1.00 & 0.00 & 1.00 & 0.00 & 1.00 & 1.00 & 1.00 & 1.00 & 1.00 & 1.00 & 0.00 & 0.00 & 1.00 & 1.00 \\
\hline K4 & 1.00 & 1.00 & 0.00 & 1.00 & 0.00 & 100 & 1.00 & 1.00 & 1.00 & 1.00 & 1.00 & 0.00 & 0.00 & 1.00 & 0.00 \\
\hline K5 & 1.00 & 1.00 & 0.00 & 1.00 & 0.00 & 1.00 & 1.00 & 1.00 & 1.00 & 1.00 & 1.00 & 0.00 & 0.00 & 1.00 & 0.00 \\
\hline 1.1 & 1.00 & 1.00 & 0.00 & 1.00 & 0.00 & 1.00 & 1.00 & 1.00 & 1.00 & 1.00 & 1.00 & 0.00 & 0.00 & 1.00 & 0.00 \\
\hline 12 & 1.00 & 1.00 & 0.00 & 1.00 & 0.00 & 100 & 1.00 & 1.00 & 1.00 & 1.00 & 1.00 & 0.00 & 0.00 & 1.00 & 1.00 \\
\hline 13 & 1.00 & 1.00 & 0.00 & 1.00 & 0.00 & 1.00 & 1.00 & 1.00 & 1.00 & 1.00 & 1.00 & 0.00 & 0.00 & 1.00 & 1.00 \\
\hline 14 & 1.00 & 1.00 & 0.00 & 1.00 & 0.00 & 1.00 & 1.00 & 1.00 & 1.00 & 1.00 & 1.00 & 0.00 & 0.00 & 1.00 & 0.00 \\
\hline 15 & 1.00 & 1.00 & 0.00 & 1.00 & 0.00 & 1.00 & 1.00 & 1.00 & 1.00 & 1.00 & 1.00 & 0.00 & 0.00 & $1.00^{2}$ & 0.00 \\
\hline sum & 52.75 & 55.75 & 0.00 & 51.75 & 8.00 & 53.00 & 52.50 & 53.00 & 60.00 & 52.00 & 53.00 & 0.00 & 0.00 & 53.00 & 11.00 \\
\hline
\end{tabular}

(a1) solid color, (a2) light color, (a3) vibrant color, (b1) fine granulation, (b2) worn material,

(b3) brushstrokes, (c1) nearness, (c2) horizontal division of the plane, (d1) lack of depth, (d2) proportions of positions, (e1) vertical axis of location, (e2) symmetry, (e3) effect of movement, (f1) closed form, and (f2) outlines. A1.. $\mathrm{L} 5$ are the coloreme regions of the corresponding Venus Table.

Table 3. Matrix of appearance of the semiotic characteristics of page 24 of the Venus Table of the Dresden Codex. 


\begin{tabular}{|c|c|c|c|c|c|c|c|c|c|c|c|c|c|c|c|}
\hline \multirow[b]{2}{*}{ Soloremi } & \multicolumn{3}{|c|}{ Plastic Characteristics } & \multirow[b]{2}{*}{ b1 } & \multirow[b]{2}{*}{ b2 } & \multirow[b]{2}{*}{ b3 } & \multirow[b]{2}{*}{ c1 } & \multirow[b]{2}{*}{ c2 } & \multirow[b]{2}{*}{ d1 } & \multirow[b]{2}{*}{ d2 2} & \multirow[b]{2}{*}{ e1 } & & & & \\
\hline & a1 & a2 & a3 & & & & & & & & & e2 & e3 & f1 & f2 \\
\hline A1 & 0.00 & 0.02 & 0.00 & 0.00 & 0.13 & 0.00 & 0.00 & 0.00 & 0.02 & 0.00 & 0.00 & 0.00 & 0.00 & 0.00 & 0.09 \\
\hline A2 & 0.02 & 0.02 & 0.00 & 0.01 & 0.06 & 0.02 & 0.01 & 0.02 & 0.02 & 0.02 & 0.02 & 0.00 & 0.00 & 0.02 & 0.00 \\
\hline A3 & 0.02 & 0.02 & 0.00 & 0.02 & 0.00 & 0.02 & 0.02 & 0.02 & 0.02 & 0.00 & 0.02 & 0.00 & 0.00 & 0.02 & 0.00 \\
\hline A4 & 0.00 & 0.02 & 0.00 & 0.00 & 0.13 & 0.00 & 0.00 & 0.00 & 0.02 & 0.00 & 0.00 & 0.00 & 0.00 & 0.00 & 0.09 \\
\hline A5 & 0.02 & 0.02 & 0.00 & 0.01 & 0.06 & 0.02 & 0.02 & 0.02 & 0.02 & 0.02 & 0.02 & 0.00 & 0.00 & 0.02 & 0.00 \\
\hline B1 & 0.00 & 0.02 & 0.00 & 0.00 & 0.13 & 0.00 & 0.00 & 0.00 & 0.02 & 0.00 & 0.00 & 0.00 & 0.00 & 0.00 & 0.00 \\
\hline B2 & 0.01 & 0.01 & 0.00 & 0.01 & 0.06 & 0.01 & 0.01 & 0.01 & 0.02 & 0.01 & 0.01 & 0.00 & 0.00 & 0.01 & 0.00 \\
\hline B3 & 0.02 & 0.02 & 0.00 & 0.02 & 0.00 & 0.02 & 0.02 & 0.02 & 0.02 & 0.02 & 0.02 & 0.00 & 0.00 & 0.02 & 0.00 \\
\hline 84 & 0.01 & 0.01 & 0.00 & 0.01 & 0.06 & 0.01 & 0.01 & 0.01 & 0.02 & 0.01 & 0.01 & 0.00 & 0.00 & 0.01 & 0.00 \\
\hline B5 & 0.01 & 0.01 & 0.00 & 0.01 & 0.06 & 0.01 & 0.01 & 0.01 & 0.02 & 0.01 & 0.01 & 0.00 & 0.00 & 0.01 & 0.00 \\
\hline C1 & 0.00 & 0.00 & 0.00 & 0.00 & 0.13 & 0.00 & 0.00 & 0.00 & 0.02 & 0.00 & 0.00 & 0.00 & 0.00 & 0.00 & 0.00 \\
\hline $\mathrm{C} 2$ & 0.00 & 0.00 & 0.00 & 0.00 & 0.06 & 0.01 & 0.01 & 0.01 & 0.02 & 0.01 & 0.01 & 0.00 & 0.00 & 0.01 & 0.09 \\
\hline C3 & 0.02 & 0.02 & 0.00 & 0.02 & 0.00 & 0.02 & 0.02 & 0.02 & 0.02 & 0.02 & 0.02 & 0.00 & 0.00 & 0.02 & 0.00 \\
\hline C4 & 0.01 & 0.01 & 0.00 & 0.01 & 0.06 & 0.01 & 0.01 & 0.01 & 0.02 & 0.01 & 0.01 & 0.00 & 0.00 & 0.01 & 0.00 \\
\hline C5 & 0.01 & 0.01 & 0,00 & 0.01 & 0.06 & 0.01 & 0.01 & 0.01 & 0.02 & 0.01 & 0.01 & 0.00 & 0.00 & 0.01 & 0.00 \\
\hline D1 & 0.02 & 0.02 & 0.00 & 0.02 & 0.00 & 0.02 & 0.02 & 0.02 & 0.02 & 0.02 & 0.02 & 0.00 & 0.00 & 0.02 & 0.00 \\
\hline D2 & 0.02 & 0.02 & 0.00 & 0.02 & 0.00 & 0.02 & 0.02 & 0.02 & 0.02 & 0.02 & 0.02 & 0.00 & 0.00 & 0.02 & 0.00 \\
\hline D3 & 0.02 & 0.02 & 0.00 & 0.02 & 0.00 & 0.02 & 0.02 & 0.02 & 0.02 & 0.02 & 0.02 & 0.00 & 0.00 & 0.02 & 0.00 \\
\hline D4 & 0.02 & 0.02 & 0.00 & 0.02 & 0.00 & 0.02 & 0.02 & 0.02 & 0.02 & 0.02 & 0.02 & 0.00 & 0.00 & 0.02 & 0.09 \\
\hline D5 & 0.02 & 0.02 & 0.00 & 0.02 & 0.00 & 0.02 & 0.02 & 0.02 & 0.02 & 0.02 & 0.02 & 0.00 & 0.00 & 0.02 & 0.00 \\
\hline E1 & 0.02 & 0.02 & 0.00 & 0.02 & 0.00 & 0.02 & 0.02 & 0.02 & 0.02 & 0.02 & 0.02 & 0.00 & 0.00 & 0.02 & 0.00 \\
\hline E2 & 0.02 & 0.02 & 0.00 & 0.02 & 0.00 & 0.02 & 0.02 & 0.02 & 0.02 & 0.02 & 0.02 & 0.00 & 0.00 & 0.02 & 0.00 \\
\hline E3 & 0.02 & 0.02 & 0.00 & 0.02 & 0.00 & 0.02 & 0.02 & 0.02 & 0.02 & 0.02 & 0.02 & 0.00 & 0.00 & 0.02 & 0.00 \\
\hline E4 & 0.02 & 0.02 & 0.00 & 0.02 & 0.00 & 0.02 & 0.02 & 0.02 & 0.02 & 0.02 & 0.02 & 0.00 & 0.00 & 0.02 & 0.00 \\
\hline E5 & 0.02 & 0.02 & 0.00 & 0.02 & 0.00 & 0.02 & 0.02 & 0.02 & 0.02 & 0.02 & 0.02 & 0.00 & 0.00 & 0.02 & 0.00 \\
\hline F1 & 0.02 & 0.02 & 0.00 & 0.02 & 0.00 & 0.02 & 0.02 & 0.02 & 0.02 & 0.02 & 0.02 & 0.00 & 0.00 & 0.02 & 0.00 \\
\hline$F 2$ & 0.02 & 0.02 & 0.00 & 0.02 & 0.00 & 0.02 & 0.02 & 0.02 & 0.02 & 0.02 & 0.02 & 0.00 & 0.00 & 0.02 & 0.09 \\
\hline F3 & 0.02 & 0.02 & 0.00 & 0.02 & 0.00 & 0.02 & 0.02 & 0.02 & 0.02 & 0.02 & 0.02 & 0.00 & 0.00 & 0.02 & 0.00 \\
\hline F4 & 0.02 & 0.02 & 0.00 & 0.02 & 0.00 & 0.02 & 0.02 & 0.02 & 0.02 & 0.02 & 0.02 & 0.00 & 0.00 & 0.02 & 0.00 \\
\hline F5 & 0.02 & 0.02 & 0.00 & 0.02 & 0.00 & 0.02 & 0.02 & 0.02 & 0.02 & 0.02 & 0.02 & 0.00 & 0.00 & 0.02 & 0.00 \\
\hline G1 & 0.02 & 0.02 & 0.00 & 0.02 & 0.00 & 0.02 & 0.02 & 0.02 & 0.02 & 0.02 & 0.02 & 0.00 & 0.00 & 0.02 & 0.00 \\
\hline G2 & 0.02 & 0.02 & 0.00 & 0.02 & 0.00 & 0.02 & 0.02 & 0.02 & 0.02 & 0.02 & 0.02 & 0.00 & 0.00 & 0.02 & 0.00 \\
\hline G3 & 0.02 & 0.02 & 0.00 & 0.02 & 0.00 & 0.02 & 0.02 & 0.02 & 0.02 & 0.02 & 0.02 & 0.00 & 0.00 & 0.02 & 0.09 \\
\hline G4 & 0.02 & 0.02 & 0.00 & 0.02 & 0.00 & 0.02 & 0.02 & 0.02 & 0.02 & 0.02 & 0.02 & 0.00 & 0.00 & 0.02 & 0.00 \\
\hline G5 & 0.02 & 0.02 & 0.00 & 0.02 & 0.00 & 0.02 & 0.02 & 0.02 & 0.02 & 0.02 & 0.02 & 0.00 & 0.00 & 0.02 & 0.00 \\
\hline $\mathrm{H} 1$ & 0.02 & 0.02 & 0.00 & 0.02 & 0.00 & 0.02 & 0.02 & 0.02 & 0.02 & 0.02 & 0.02 & 0.00 & 0.00 & 0.02 & 0.00 \\
\hline $\mathrm{H} 2$ & 0.02 & 0.02 & 0,00 & 0.02 & 0.00 & 0.02 & 0.02 & 0.02 & 0.02 & 0.02 & 0.02 & 0.00 & 0.00 & 0.02 & 0.00 \\
\hline H3 & 0.02 & 0.02 & 0.00 & 0.02 & 0.00 & 0.02 & 0.02 & 0.02 & 0.02 & 0.02 & 0.02 & 0.00 & 0.00 & 0.02 & 0.00 \\
\hline $\mathrm{H} 4$ & 0.02 & 0.02 & 0.00 & 0.02 & 0.00 & 0.02 & 0.02 & 0.02 & 0.02 & 0.02 & 0.02 & 0.00 & 0.00 & 0.02 & 0.00 \\
\hline H5 & 0.02 & 0.02 & 0.00 & 0.02 & 0.00 & 0.02 & 0.02 & 0.02 & 0.02 & 0.02 & 0.02 & 0.00 & 0.00 & 0.02 & 0.00 \\
\hline I1 & 0.02 & 0.02 & 0.00 & 0.02 & 0.00 & 0.02 & 0.02 & 0.02 & 0.02 & 0.02 & 0.02 & 0.00 & 0.00 & 0.02 & 0.00 \\
\hline 12 & 0.02 & 0.02 & 0.00 & 0.02 & 0.00 & 0.02 & 0.02 & 0.02 & 0.02 & 0.02 & 0.02 & 0.00 & 0.00 & 0.02 & 0.09 \\
\hline 13 & 0.02 & 0.02 & 0.00 & 0.02 & 0.00 & 0.02 & 0.02 & 0.02 & 0.02 & 0.02 & 0.02 & 0.00 & 0.00 & 0.02 & 0.00 \\
\hline 14 & 0.02 & 0.02 & 0.00 & 0.02 & 0.00 & 0.02 & 0.02 & 0.02 & 0.02 & 0.02 & 0.02 & 0.00 & 0.00 & 0.02 & 0.00 \\
\hline 15 & 0.02 & 0.02 & 0.00 & 0.02 & 0.00 & 0.02 & 0.02 & 0.02 & 0.02 & 0.02 & 0.02 & 0.00 & 0.00 & 0.02 & 0.00 \\
\hline J1 & 0.02 & 0.02 & 0.00 & 0.02 & 0.00 & 0.02 & 0.02 & 0.02 & 0.02 & 0.02 & 0.02 & 0.00 & 0.00 & 0.02 & 0.00 \\
\hline J2 & 0.02 & 0.02 & 0.00 & 0.02 & 0.00 & 0.02 & 0.02 & 0.02 & 0.02 & 0.02 & 0.02 & 0.00 & 0.00 & 0.02 & 0.00 \\
\hline J3 & 0.02 & 0.02 & 0.00 & 0.02 & 0.00 & 0.02 & 0.02 & 0.02 & 0.02 & 0.02 & 0.02 & 0.00 & 0.00 & 0.02 & 0.00 \\
\hline J4 & 0.02 & 0.02 & 0.00 & 0.02 & 0.00 & 0.02 & 0.02 & 0.02 & 0.02 & 0.02 & 0.02 & 0.00 & 0.00 & 0.02 & 0.09 \\
\hline J5 & 0.02 & 0.02 & 0.00 & 0.02 & 0.00 & 0.02 & 0.02 & 0.02 & 0.02 & 0.02 & 0.02 & 0.00 & 0.00 & 0.02 & 0.00 \\
\hline K1 & 0.02 & 0.02 & 0.00 & 0.02 & 0.00 & 0.02 & 0.02 & 0.02 & 0.02 & 0.02 & 0.02 & 0.00 & 0.00 & 0.02 & 0.00 \\
\hline K2 & 0.02 & 0.02 & 0.00 & 0.02 & 0.00 & 0.02 & 0.02 & 0.02 & 0.02 & 0.02 & 0.02 & 0.00 & 0.00 & 0.02 & 0.00 \\
\hline K3 & 0.02 & 0.02 & 0.00 & 0.02 & 0.00 & 0.02 & 0.02 & 0.02 & 0.02 & 0.02 & 0.02 & 0.00 & 0.00 & 0.02 & 0.09 \\
\hline K4 & 0.02 & 0.02 & 0.00 & 0.02 & 0.00 & 0.02 & 0.02 & 0.02 & 0.02 & 0.02 & 0.02 & 0.00 & 0.00 & 0.02 & 0.00 \\
\hline K5 & 0.02 & 0.02 & 0.00 & 0.02 & 0.00 & 0.02 & 0.02 & 0.02 & 0.02 & 0.02 & 0.02 & 0.00 & 0.00 & 0.02 & 0.00 \\
\hline L1 & 0.02 & 0.02 & 0.00 & 0.02 & 0.00 & 0.02 & 0.02 & 0.02 & 0.02 & 0.02 & 0.02 & 0.00 & 0.00 & 0.02 & 0.00 \\
\hline L2 & 0.02 & 0.02 & 0.00 & 0.02 & 0.00 & 0.02 & 0.02 & 0.02 & 0.02 & 0.02 & 0.02 & 0.00 & 0.00 & 0.02 & 0.09 \\
\hline L3 & 0.02 & 0.02 & 0.00 & 0.02 & 0.00 & 0.02 & 0.02 & 0.02 & 0.02 & 0.02 & 0.02 & 0.00 & 0.00 & 0.02 & 0.09 \\
\hline L4 & 0.02 & 0.02 & 0.00 & 0.02 & 0.00 & 0.02 & 0.02 & 0.02 & 0.02 & 0.02 & 0.02 & 0.00 & 0.00 & 0.02 & 0.00 \\
\hline L.5 & 0.02 & 0.02 & 0.00 & 0.02 & 0.00 & 0.02 & 0.02 & 0.02 & 0.02 & 0.02 & 0.02 & 0.00 & 0.00 & 0.02 & 0.00 \\
\hline SUM & 1.00 & 1.00 & 0.00 & 1.00 & 1.00 & 1.00 & 1.00 & 1.00 & 1.00 & 1.00 & 1.00 & 0.00 & 0.00 & 1.00 & 1.00 \\
\hline
\end{tabular}

(a1) solid color, (a2) light color, (a3) vibrant color, (b1) fine granulation, (b2) worn material, (b3) brushstrokes, (c1) nearness, (c2) horizontal division of the plane, (d1) lack of depth, (d2) proportions of positions, (e1) vertical axis of location, (e2) symmetry, (e3) effect of movement, (f1) closed form, and (f2) outlines. A1... L5 are the coloreme regions of the corresponding Venus Table.

Table 4. Stochastic matrix from page 24 of the Venus table of the Dresden Codex. 


\begin{tabular}{|c|c|c|c|c|c|c|c|c|c|c|c|c|c|c|c|}
\hline \multirow{2}{*}{ Coloremi } & \multicolumn{3}{|c|}{ Plastic Characteristics } & \multirow[b]{2}{*}{ b1 } & \multirow[b]{2}{*}{ b2 } & \multirow[b]{2}{*}{ b3 } & \multirow[b]{2}{*}{ c1 } & \multirow[b]{2}{*}{0} & \multirow[b]{2}{*}{ d1 } & \multirow[b]{2}{*}{ d2 } & \multirow[b]{2}{*}{ e1 } & & & & \\
\hline & al & a2 & 33 & & & & & & & & & $\bullet 2$ & e3 & $f 1$ & 12 \\
\hline A1 & 0.00 & -0.08 & 0.00 & 0.00 & -0.08 & 0.00 & 0.00 & 0.00 & $0 . \infty 8$ & 0.00 & 0.00 & 0.00 & 0.00 & 0.00 & -0.22 \\
\hline$A 2$ & -0.08 & -0.08 & 0.00 & -0.05 & -0.17 & $-0.08^{\prime}$ & -0.05 & -0.08 & -0.08 & -0.08 & -0.08 & 0.00 & 0.00 & -0.08 & 0.00 \\
\hline$A 3$ & -0.08 & -0.08 & 0.00 & -0.08 & 0.00 & -0.08 & -0.08 & -0.08 & -0.08 & 0.00 & -0.08 & 0.00 & 0.00 & -0.08 & 0.00 \\
\hline A4 & 0.00 & $-0,08$ & 0.00 & 0,00 & -0.27 & 0.00 & 0,00 & 0.00 & -0.08 & 0.00 & 0.00 & 0,00 & 0.00 & 0.00 & -0.22 \\
\hline A5 & -0.08 & -0.08 & 0.00 & .0 .05 & -0.17 & .0 .08 & -0.08 & -0.08 & -0.08 & .0 .08 & -0.08 & 0.00 & 0,00 & $-0,08$ & 0.00 \\
\hline 81 & 0.00 & -0.08 & 0.00 & 0.00 & -0.27 & 0.00 & 0.00 & 0.00 & -0.08 & 0.00 & 0.00 & 0.00 & 0.00 & 0.00 & 0.00 \\
\hline 82 & $-0.05^{r}$ & -0.05 & 0.00 & -0.05 & -0.27 & -0.05 & -0.05 & -0.05 & -0.08 & -0.05 & -0.05 & 0.00 & 0.00 & -0.05 & 0.00 \\
\hline B3 & $-0,08$ & $-0,08$ & 0.00 & $=0.08$ & $0.00^{\prime}$ & $\cdot 0.08^{n}$ & $-0.08^{r}$ & $-0,08$ & $-0.08^{\prime}$ & $.0 .08^{n}$ & -0.08 & 0.00 & $0.00^{7}$ & -0.08 & 0.00 \\
\hline 84 & -0.05 & -0.05 & 0.00 & -0.05 & -0.27 & -0.05 & -0.05 & -0.05 & -0.08 & -0.05 & -0.05 & 0.00 & 0.00 & -0.05 & 0.00 \\
\hline 85 & -0.05 & -0.05 & 0.00 & -0.05 & -0.17 & -0.05 & -0.05 & $-0.05^{\prime}$ & -0.08 & -0.05 & -0.05 & 0.00 & 0.00 & -0.05 & 0.00 \\
\hline $\mathrm{Cl}$ & 0.00 & 0.00 & 0.00 & 0,00 & -0.27 & 0.00 & 0,00 & 0.00 & -0.08 & 0.00 & 0.00 & 0.00 & 0.00 & 0.00 & 0.00 \\
\hline C2 & 0.00 & 0.00 & 0.00 & 0.00 & -0.27 & .0 .05 & -0.05 & -0.05 & $-0 . \infty$ & -0.05 & .0 .05 & 0.00 & 0.00 & -0.05 & -0.22 \\
\hline C3 & -0.08 & -0.08 & 0.00 & -0.08 & $0.00^{\prime}$ & $-0.08^{\prime \prime}$ & $-0.08^{\prime}$ & -0.08 & $-0.08^{\prime}$ & $-0,08^{\prime}$ & -0.08 & 0.00 & $0.00^{7}$ & -0.08 & 0.00 \\
\hline$C 4$ & -0.05 & -0.05 & 0.00 & -0.05 & -0.27 & -0.05 & -0.05 & $-0.05^{5}$ & -0.08 & $-0,05$ & -0.05 & 0.00 & 0.00 & -0.05 & 0.00 \\
\hline$C 5$ & -0.05 & -0.05 & 0.00 & .0 .05 & -0.27 & .0 .05 & -0.05 & $-0.05^{5}$ & -0.08 & -0.05 & .0 .05 & 0.00 & 0.00 & 0.05 & 0.00 \\
\hline D1 & -0.08 & -0.08 & 0.00 & -0.08 & 0.00 & -0.08 & -0.08 & -0.08 & -0.08 & -0.08 & -0.08 & 0.00 & 0.00 & -0.08 & 0.00 \\
\hline D2 & -0.08 & -0.08 & 0.00 & $-0,08$ & 0.00 & -0.08 & -0.08 & -0.08 & -0.08 & -0.08 & -0.08 & 0.00 & 0.00 & -0.08 & 0.00 \\
\hline D3 & -0.08 & -0.08 & 0.00 & -0.08 & 0.00 & -0.08 & -0.08 & -0.08 & -0.08 & -0.08 & -0.08 & 0.00 & 0.00 & -0.08 & 0.00 \\
\hline D4 & -0.08 & -0.08 & 0.00 & $-0,08$ & 0.00 & -0.08 & -0.08 & 0.08 & 0.08 & -0.08 & -0.08 & 0.00 & 0.00 & -0.08 & -0.22 \\
\hline os & -0.08 & -0.08 & 0.00 & -0.08 & 0.00 & -0.08 & -0.08 & -0.08 & -0.08 & -0.08 & -0.08 & 0.00 & 0.00 & -0.08 & 0.00 \\
\hline E1 & -0.08 & -0.08 & 0.00 & -0.08 & 0.00 & -0.08 & -0.08 & -0.08 & -0.08 & -0.08 & -0.08 & 0.00 & 0.00 & -0.08 & 0.00 \\
\hline E2 & -0.08 & -0.08 & 0.00 & -0.08 & 0.00 & -0.08 & -0.08 & -0.08 & .0 .08 & $-0,08$ & -0.08 & 0.00 & 0.00 & $-0,08$ & 0.00 \\
\hline E3 & -0.08 & -0.08 & 0.00 & -0.08 & 0.00 & -0.08 & -0.08 & -0.08 & -0.08 & -0.08 & -0.08 & 0.00 & 0.00 & -0.08 & 0.00 \\
\hline E4 & -0.08 & -0.08 & 0.00 & -0.08 & 0.00 & -0.08 & -0.08 & -0.08 & -0.08 & -0.08 & -0.08 & 0.00 & 0.00 & -0.08 & 0.00 \\
\hline ES & -0.08 & -0.08 & 0.00 & 0.08 & 0.00 & -0.08 & -0.08 & -0.08 & -0.08 & -0.08 & -0.08 & 0.00 & 0.00 & -0.08 & 0.00 \\
\hline$F 1$ & -0.08 & -0.08 & 0.00 & -0.08 & 0.00 & -0.08 & -0.08 & -0.08 & -0.08 & -0.08 & -0.08 & 0.00 & 0.00 & -0.08 & 0.00 \\
\hline$F 2$ & -0.08 & -0.08 & 0.00 & -0.08 & 0.00 & .0 .08 & -0.08 & -0.08 & -0.08 & -0.08 & -0.08 & 0.00 & 0.00 & -0.08 & -0.22 \\
\hline $\mathrm{FH}$ & -0.08 & -0.08 & 0.00 & -0.08 & 0.00 & -0.08 & -0.08 & -0.08 & -0.08 & -0.08 & -0.08 & 0.00 & 0.00 & -0.08 & 0.00 \\
\hline F4 & -0.08 & -0.08 & 0.00 & -0.08 & 0.00 & -0.08 & -0.08 & -0.08 & -0.08 & -0.08 & -0.08 & 0.00 & 0.00 & -0.08 & 0.00 \\
\hline FS & 0.08 & -0.08 & 0.00 & -0.08 & 0.00 & -0.08 & -0.08 & -0.08 & -0.08 & -0.08 & -0.08 & 0.00 & 0.00 & 0.08 & 0.00 \\
\hline G1 & -0.08 & -0.08 & 0.00 & -0.08 & 0.00 & -0.08 & -0.08 & -0.08 & -0.08 & -0.08 & -0.08 & 0.00 & 0.00 & -0.08 & 0.00 \\
\hline G2 & -0.08 & -0.08 & 0.00 & -0.08 & 0.00 & -0.08 & -0.08 & -0.08 & -0.08 & -0.08 & -0.08 & 0.00 & 0.00 & -0.08 & 0.00 \\
\hline G3 & -0.08 & -0.08 & 0.00 & -0.08 & 0.00 & -0.08 & -0.08 & -0.08 & -0.08 & -0.08 & -0.08 & 0.00 & 0.00 & -0.08 & -0.22 \\
\hline G4 & -0.08 & -0.08 & 0.00 & -0.08 & 0.00 & -0.08 & -0.08 & -0.08 & -0.08 & -0.08 & -0.08 & 0.00 & 0.00 & 0.08 & 0.00 \\
\hline G5 & -0.08 & -0.08 & 0.00 & -0.08 & 0.00 & -0.08 & -0.08 & -0.08 & -0.08 & -0.08 & -0.08 & 0.00 & 0.00 & -0.08 & 0.00 \\
\hline $\mathrm{H} 1$ & -0.08 & -0.08 & 0.00 & -0.08 & 0.00 & -0.08 & -0.08 & -0.08 & -0.08 & -0.08 & -0.08 & 0.00 & 0.00 & -0.08 & 0,00 \\
\hline $\mathrm{H} 2$ & -0.08 & -0.08 & 0.00 & -0.08 & 0.00 & -0.08 & -0.08 & -0.08 & -0.08 & -0.08 & -0.08 & 0.00 & 0.00 & -0.08 & 0.00 \\
\hline H3 & -0.08 & -0.08 & 0.00 & -0.08 & 0.00 & -0.08 & -0.08 & -0.08 & -0.08 & -0.08 & -0.08 & 0.00 & 0.00 & -0.08 & 0.00 \\
\hline $\mathrm{H}_{4}$ & -0.08 & -0.08 & 0.00 & -0.08 & 0.00 & -0.08 & -0.08 & -0.08 & -0.08 & -0.08 & -0.08 & 0.00 & 0.00 & -0.08 & 0.00 \\
\hline HS & $-0,08$ & -0.08 & 0.00 & -0.08 & 0.00 & -0.08 & -0.08 & -0.08 & -0.08 & -0.08 & -0.08 & 0.00 & 0.00 & -0.08 & 0.00 \\
\hline 11 & -0.08 & -0.08 & 0.00 & -0.08 & 0.00 & -0.08 & -0.08 & -0.08 & 0.08 & -0.08 & -0.08 & 0.00 & 0.00 & -0.08 & 0.00 \\
\hline 12 & -0.08 & -0.08 & 0.00 & 0.08 & 0.00 & -0.08 & -0.08 & -0.08 & -0.08 & -0.08 & -0.08 & 0.00 & 0.00 & -0.08 & -0.22 \\
\hline 13 & -0.08 & -0.08 & 0.00 & -0.08 & 0.00 & -0.08 & -0.08 & -0.08 & -0.08 & .0 .08 & -0.08 & 0.00 & 0.00 & -0.08 & 0.00 \\
\hline 14 & -0.08 & -0.08 & 0.00 & -0.08 & 0.00 & -0.08 & -0.08 & -0.08 & -0.08 & -0.08 & -0.08 & 0.00 & 0.00 & -0.08 & 0.00 \\
\hline 15 & -0.08 & -0.08 & 0.00 & -0.08 & 0.00 & -0.08 & -0.08 & -0.08 & -0.08 & -0.08 & -0.08 & 0.00 & 0.00 & -0.08 & 0.00 \\
\hline 11 & -0.08 & -0.08 & 0.00 & -0.08 & 0.00 & -0.08 & $-0,08$ & -0.08 & -0.08 & -0.08 & -0.08 & 0.00 & 0.00 & -0.08 & 0.00 \\
\hline 12 & -0.08 & -0.08 & 0.00 & -0.08 & 0.00 & -0.08 & -0.08 & -0.08 & -0.08 & -0.08 & -0.08 & 0.00 & 0.00 & -0.08 & 0.00 \\
\hline J3 & -0.08 & -0.08 & 0.00 & -0.08 & 0.00 & -0.08 & -0.08 & -0.08 & -0.08 & -0.08 & -0.08 & 0.00 & 0.00 & -0.08 & 0.00 \\
\hline 14 & -0.08 & -0.08 & 0.00 & -0.08 & 0.00 & -0.08 & -0.08 & $-0,08$ & -0.08 & -0.08 & -0.08 & 0.00 & 0.00 & -0.08 & -0.22 \\
\hline 15 & 0.08 & -0.08 & 0.00 & -0.08 & 0.00 & -0.08 & -0.08 & -0.08 & 0.08 & -0.08 & -0.08 & 0.00 & 0.00 & -0.08 & 0.00 \\
\hline$K_{1}$ & -0.08 & -0.08 & 0.00 & -0.08 & 0.00 & -0.08 & -0.08 & -0.08 & -0.08 & -0.08 & -0.08 & 0.00 & 0.00 & -0.08 & 0.00 \\
\hline$K_{2} 2$ & -0.08 & -0.08 & 0.00 & -0.08 & 0.00 & $\cdot 0.08$ & -0.08 & -0.08 & -0.08 & -0.08 & -0.08 & 0.00 & 0.00 & -0.08 & 0.00 \\
\hline $\mathrm{kJ}$ & -0.08 & -0.08 & 0.00 & -0.08 & 0.00 & -0.08 & -0.08 & -0.08 & -0.08 & -0.08 & -0.08 & 0.00 & 0.00 & -0.08 & -0.22 \\
\hline K4 & -0.08 & -0.08 & 0.00 & -0.08 & 0.00 & -0.08 & -0.08 & $-0,08$ & -0.08 & -0.08 & -0.08 & 0.00 & 0.00 & -0.08 & 0.00 \\
\hline $\mathrm{KS}$ & -0.08 & -0.08 & 0.00 & -0.08 & 0.00 & -0.08 & -0.08 & -0.08 & -0.08 & -0.08 & -0.08 & 0.00 & 0.00 & -0.08 & 0.00 \\
\hline เ1 & $-0,0 B$ & -0.08 & 0.00 & $-0,08$ & 0.00 & -0.08 & -0.08 & -0.08 & -0.08 & -0.08 & -0.08 & 0.00 & 0.00 & -0.08 & 0.00 \\
\hline 12 & $-0,08$ & -0.08 & 0.00 & -0.08 & 0.00 & -0.08 & -0.08 & -0.08 & -0.08 & -0.08 & -0.08 & 0.00 & 0.00 & -0.08 & -0.22 \\
\hline 13 & -0.08 & -0.08 & 0.00 & -0.08 & 0.00 & -0.08 & $-0,08$ & -0.08 & -0.08 & -0.08 & $-0.0 B$ & 0.00 & 0,00 & -0.08 & -0.22 \\
\hline L4 & -0.08 & -0.08 & 0.00 & -0.08 & 0.00 & -0.08 & -0.08 & -0.08 & -0.08 & -0.08 & -0.08 & 0.00 & 0.00 & 0.08 & 0.00 \\
\hline$L 5$ & -0.08 & -0.08 & 0.00 & -0.08 & 0.00 & -0.08 & -0.08 & -0.08 & -0.08 & -0.08 & -0.08 & 0.00 & 0.00 & -0.08 & 0.00 \\
\hline SUN & 4.14 & 4.38 & 0.00 & 4.08 & 2.73 & 4.19 & 4.16 & 4.19 & 4.69 & 4.11 & 4.19 & 0.00 & 0.00 & 4.19 & 2.2 \\
\hline
\end{tabular}

(a1) solid color, (a2) light color, (a3) vibrant color, (b1) fine granulation, (b2) worn material, (b3) brushstrokes, (c1) nearness, (c2) horizontal division of the plane, (d1) lack of depth, (d2) proportions of positions, (e1) vertical axis of location, (e2) symmetry, (e3) effect of movement, (f1) closed form, and (f2) outlines. A1... L5 are the coloreme regions of the corresponding Venus Table.

Table 5. Applying equation 1 of Shannon's entropy to each coloreme and semiotic variable of Page 24 of the Venus table of the Dresden Codex. 
positive due to the effect of the minus sign on equation $1\left(H=-\sum p i \log p i\right)$. Table 5 shows the results of this calculation for Page 24 of the Venus Table.

Step 11. Obtaining entropy for each semiotic variable and each page of the Venus table of the Dresden Codex

We calculated Shannon's $\mathrm{H}$ entropy for each of the six paintings of the Venus cycle, as shown in Table 5. This allowed for formulating the results of entropy in bits or units of information of the Venus Table, according to the method established by Shannon. Table 6 shows $\mathrm{H}$ entropy in bits, or quantity of information of the Venus table of the Dresden Codex, in order to compare the six paintings or pages.

\begin{tabular}{|c|c|c|c|c|c|c|c|c|c|c|c|c|c|c|c|}
\hline & \multicolumn{15}{|c|}{ Visual Characteristics } \\
\hline & a1 & $\mathrm{a} 2$ & a3 & b1 & b2 & b3 & c1 & c2 & $\begin{array}{ll}\mathrm{d} 1 \\
\end{array}$ & d2 & e1 & $\mathrm{e} 2$ & e3 & $\mathrm{f1}$ & f2 \\
\hline & \multicolumn{15}{|c|}{ H entropy in bits } \\
\hline \begin{tabular}{|l|} 
Page 24 \\
\end{tabular} & & & & & & & & & & & & & & & \\
\hline $47 \cdot 30=$ & 4.14 & 4.38 & 0 & 4.08 & 2.73 & 4.19 & 4.14 & 4.19 & 4.69 & 4.11 & 4.19 & 0 & 0 & 4.19 & 2.25 \\
\hline \begin{tabular}{|c|} 
Page 46 \\
$50.48=$
\end{tabular} & 4.05 & 3.89 & 0 & 4.27 & 2.74 & 4.16 & 4.22 & 4.27 & 4.69 & 3.41 & 4.28 & 0 & 2.32 & 4.20 & 3.98 \\
\hline \begin{tabular}{|c|} 
Page 47 \\
$49.78=$
\end{tabular} & 4.00 & 3.49 & 0 & 4.20 & 2.28 & 4.16 & 4.16 & 4.22 & 4.60 & 3.69 & 4.22 & 0 & 2.56 & 4.22 & 3.98 \\
\hline \begin{tabular}{|c|} 
Page 48 \\
$51.77=$ \\
\end{tabular} & 4.22 & 3.54 & 0 & 4.46 & 1.10 & 4.20 & 4.55 & 4.47 & 4.46 & 4.65 & 4.71 & 0 & 2.77 & 4.66 & 3.98 \\
\hline \begin{tabular}{|c|} 
Page 49 \\
$49.92=$
\end{tabular} & 4.28 & 3.76 & 0 & 4.43 & 1.10 & 4.31 & 4.33 & 4.25 & 4.70 & 4.31 & 4.37 & 0 & 2.39 & 4.33 & 3.36 \\
\hline \begin{tabular}{|c|} 
Page 50 \\
$51.86=$
\end{tabular} & 4.27 & 3.62 & 0 & 4.27 & 2.42 & 4.24 & 4.23 & 4.16 & 4.70 & 4.18 & 4.23 & 0 & 3.20 & 4.23 & 4.11 \\
\hline
\end{tabular}

(a1) solid color, (a2) light color, (a3) vibrant color, (b1) fine granulation, (b2) worn material, (b3) brushstrokes, (c1) nearness, (c2) horizontal division of the plane, (d1) lack of depth, (d2) proportions of positions, (e1) vertical axis of location, (e2) symmetry, (e3) effect of movement, (f1) closed form, and (f2) outlines.

Table 6. Shannon entropy $\mathrm{H}$ or information contained in the Venus tables of the Dresden Codex by page and visual characteristics.

\section{Results and Discussion}

This study determined the amount of information contained in the Venus Table on pages 24 and 46 to 50 of the Dresden Codex in order to compare levels of variation of information among paintings, which is not possible with aesthetic descriptions. The significant aspect of the value of entropy $\mathrm{H}$ is that when a message or a painting can be distinguished from others of the same type, the proportion of individual characteristics with respect to semiotic variables and coloremes regions is unlikely to resemble the proportion of characteristics of the other paintings. And when a message is very likely to show no differences among semiotic variables -in this case that all Venus pages - are equal the value of $\mathrm{H}$ would be very small, or almost zero.

In the visual description, we mentioned that pages 46 to 50 had a surprising level of homogeneity. Nevertheless, the entropy value obtained allowed for determining variations among pages or paints. Page 50 has the highest entropy 
value (51.86 bits) and page 24 the lowest (47.30 bits). Page 24 contains only calendric numeric notation; it does not include any image of Venus, the regent, or the victim, as do the other five pages. None of the Venus pages have an entropy value of zero, meaning that the message of the paintings is not easily predictable for the 15 semiotic characteristics (Table 6).

Two semiotic characteristics have an entropy value of zero bits (a3 and e2). This means that the message transmitted by these characteristics is very predictable. That is, in the Venus Table none of the pictorial messages contain vibrant colors or luminosity, neither symmetry or orientation of the plane. With respect to the characteristic "solid color" (a1), or the appearance of intensity of a color, there is little variability among the Venus pages: entropy ranges from 4.00 bits on page 47 to 4.28 bits on page 49 . All the pages have completely defined colors for some of the chromatic poles mentioned. With respect to the characteristic "light color" (a2), or intensity of a light color, page 24 has the highest entropy value (4.38 bits), while values range from 3.49 bits to 3.89 bits for the other pages. As mentioned, page 24 does not include any image and the background is white, and therefore is clearer than the rest of the tables.

For the characteristic "fine granulation" (b1), referring to the surface on which a pigment is applied, the entire Venus Table has a fairly fine-grained texture. Entropy ranges from 4.08 bits on page 24 to 4.43 bits on page 49 . The characteristic "worn material" (b2) determined the level of deterioration or fraying of the pages. Pages 48 and 49 are the least deteriorated, with entropy of 1.10 bits. The most deteriorated are 46 and 24, with entropy of 2.74 bits and 2.73 bits, respectively. Regarding texture, all the Venus pages show "brushstrokes" (b3), or the manner in which pigments were physically dispersed. Entropy ranges from 4.16 bits on pages 46 and 47 to 4.31 bits on page 49 .

With respect to the characteristic "nearness" (c1), or the perception of proximity among elements in the visual field, all the Venus Table show tension in the size of the formants, and proportionality among the neighboring blocks. Therefore, entropy varies little, ranging from 4.14 bits on page 24 to 4.55 bits on page 48. In relation to the characteristic "horizontal division of the plane" (c2), or the optical effect of position in the plane, the entropy value varies little, ranging from 4.14 bits on page 24 to 4.55 bits on page 48 . That is, the formants are visually perceived to be placed horizontally within the plane.

The characteristic "lack of depth" (d1), or the orientation of the formants in three spatial dimensions, along with characteristics a3 and e2, are the most homogenous. The position of the formants lacks depth, and entropy values range from 4.46 bits to 4.70 bits. The characteristic "proportions of positions" (d2), or relative position of groups of coloremes in the visual field, indicates that the observer upon perceiving the space detects outlines and creates the illusory effect of position in the plane. The Venus Table reveals proportion of positions; page 46 shows a lesser effect than that of page 48 , with entropy values of 3.41 bits and 4.65 bits, respectively. 
The characteristic "vertical axis of location" (e1), or the orientation of the formants in three spatial dimensions, addresses the relationships between near and far regions within the visual field. The elements of each Venus page appear to be oriented according to a vertical axis, as demonstrated by entropy values ranging from 4.19 bits for page 24 to 4.71 bits for page 48 . For the characteristic "movement effect" (e3), or the perception of forces that produce movement, page 24 has no images and therefore shows no movement and has entropy of zero, while on pages 46 to 49 , the images of Venus and the victim show movement, with entropy values ranging from 2.32 bits to 2.77 bits. On page 50, all three images show movement, and entropy is 3.20 bits.

The characteristic "closed form" (f1), or the perceptual characteristic between two neighboring regions in the visual field, indicates the transition from one visual zone to another with diffuse outlines. The Venus Table have undefined borders due to the forms of the glyphs. The lowest entropy value is 4.19 bits on page 24, and the highest 4.66 bits for page 48 . Finally, the characteristic "outlines" (f2), or the borders which mark the division among visual zones, indicates distinct lines separating one visual zone from another. The Venus Table has borders around the images of the regent, Venus, and the victim, as well as borders around each page. Page 50 has the clearest borders - throughout the page- with an entropy value of 4.11 bits. Page 24 has the lowest entropy value -2.25 bits-, while pages 48 and 49 both have entropy value of 3.98 bits.

\section{Final Comments}

In the prologue of Miguel León Portilla's book (León Portilla, 1994: 13), and in an introductory note of Anthony Aveni's book (Aveni, 1991: 154), Eric Thompson warns us that it is difficult for someone from twentieth-century western culture to fully comprehend the mystic and emotional nature of Maya philosophy of time. Our cultural education impedes us to appreciate the value of the Maya belief system because Mesoamerican thought was dominated by the principle of cosmic existence, which tends to be incompatible with our Cartesian thought.

The Venus Table of the Dresden Codex is not only a painting on a foldout canvas; it communicates a calendrical message that has taken 500 years to decipher. The Maya described their calendrical knowledge with mathematical operations using positional numeric notation to explain the functioning of the sacred 260day calendar in a cycle of 8 terrestrial years. This knowledge is represented by glyphs that include the names of the days, the cardinal directions, and personifications of Venus.

The astronomical-astrological knowledge that the Mayan painters wished to transmit through pictorial images of the almanacs and prophecies were representations of their thoughts, which were expressed in the Maya Ch'olan language. So, the visual semiotic message decoded from their paintings may not 
only be interpreted by a Maya priest but rather by any trained person of the $21^{\text {st }}$ century.

This decoding system allows for understanding the function of the Venus Table, which was to connect the ritual celebration of a significant celestial position in the cycle of Venus with civic, religious, and agricultural aspects of daily life. This required precise comprehension of the synchrony of planetary movements with the heavenly cycles. The Maya ideology regarding time, which was based on their knowledge of planetary synchronization, formed part of their worldview.

Shannon's entropy is a value of reference that allows us to recognize the structure of the message in a cultural object such as a painting and determine its levels of uniqueness. That is, the information contained in paintings in which visual and perception characteristics can be codified, and then conveyed through by a channel and decode in a message, can be compared, reproduced exactly or approximately in another point knowing the entropy value. Furthermore, SaintMartin's visual semiotics method of analysis allows for correlating ocular fixation with objective and perceptual characteristics to contrast objects, regardless of who evaluates the object.

By applying visual semiotic analysis, as presented in this study, as well as to determine the entropy of an artistic work, as the paintings of the Venus Table of a pre-Columbian manuscript, it is possible to explain the practical functioning of knowledge that underlies a system of meaning, such as that contained in a pictorial work of art, and to offer data that allows us to compare old and modern paintings.

\section{Acknowledgements}

We thank the Foundation for the Advancement of Mesoamerican Studies < http:// www.famsi.org/spanish/index.html $>$, for their generosity in making available the Dresden Codex on the Internet for pre-Columbian research.

\section{References}

Aveni, Anthony F.

1979 "Venus and the Maya", American Scientist, 67 (3): 274-285.

1991 Observadores del cielo en el México antiguo. México: Fondo de Cultura Económica.

Bricker, Harvey M., and Victoria R. Bricker

2011 Astronomy in the Maya Codices. Philadelphia: American Philosophical Society.

Códice de Dresde

1983 Facsímil. México: Fondo de Cultura Económica. 
Códice de Dresde

$2019<$ <ttp://www.famsi.org/spanish/mayawriting/codices/dresden.html > . Foundation for the Advancement of Mesoamerican Studies [accessed April 3rd, 2019].

Coe, Michael D.

1996 El desciframiento de los glifos mayas. México: Fondo de Cultura Económica.

Ferro Ramos, Isabel

1999 Diccionario de Astronomía. México: Fondo de Cultura Económica.

Freidel David, Linda Schele and Joy Parker

2001 El cosmos maya. Tres mil años por la senda de los chamanes. México: Fondo de Cultura Económica.

Fuls, Andreas

2002 "Schrift und Astronomie der Maya", Megalithos, 4 (2): 146-149.

2008 "Reanalysis of Dating the Classic Maya Culture", Amerindian Research Band, 3

(9): 132-146.

García-Colín Scherer, Leopoldo

1972 Introducción a la termodinámica clásica. México: Editorial Trillas.

Greimas, Algirdas J.

1994 "Semiótica figurativa y semiótica plástica”, Figuras y estrategias: En torno de una semiótica de lo visual, pp. 17-42, Gabriel Hernández (selección, traducción e introducción). México: Siglo XXI, Benemérita Universidad Autónoma de Puebla.

Kettunen, Harri and Christophe Helmke

2011 Introducción a los jeroglíficos mayas. XVI Conferencia Maya Europea. Copenhague: Departamento de Lenguas y Culturas Indígenas, Universidad de Copenhague.

León-Portilla, Miguel

1994 Tiempo y realidad en el pensamiento maya. Ensayo de acercamiento, $3^{\text {a }}$ edición. México: Universidad Nacional Autónoma de México.

Martin, Simon and Nikolai Grube

2002 Crónica de los reyes y reinas mayas. La primera historia de las dinastías mayas. Barcelona: Planeta.

Milbrath, Susan

1999 Star Gods of the Maya: Astronomy in Art, Folklore, and Calendars. Austin: University of Texas Press.

Nöth, Winfried

1995 Handbook of Semiotics. Advances in Semiotics. Indiana: Indiana University Press. 
Pallán Gayol, Carlos

2011 Breve historia de los mayas. Madrid: Nowtilus.

Proskouriakoff, Tatiana

2007 Historia maya. México: Siglo XXI.

Rice, Prudence

2007 Maya Calendar Origins. Monuments, Mythistory, and the Materialization of Time. Austin: University of Texas Press.

Salgado Ruelas, Silvia M.

2001 Análisis semiótico de la forma arbórea en el Códice de Dresde. México: Universidad Nacional Autónoma de México.

Saint-Martin, Fernande

1990 Semiotics of Visual Language. Bloomington and Indianapolis: Indiana University Press.

Savater, Fernando

2003 "Perdidos en el tiempo", Las preguntas de la vida, pp. 241-264. México: Ariel.

Schmidt, Peter, Mercedes de la Garza and Enrique Nalda (coords.)

1999 Los mayas. México y Milán: Consejo Nacional para la Cultura y las Artes, Instituto Nacional de Antropología e Historia, Landucci Editores.

Shannon, Claude E.

1948 "A Mathematical Theory of Communication", The Bell Technical System Journal, XXVII (3): 379-423. DoI: https://doi.org/10.1002/j.1538-7305.1948. tb01338.x.

Shannon, Claude E., and Warren Weaver

1998 The Mathematical Theory of Communication. Urbana: University of Illinois Press.

Sonesson, Göran

2016 "Current Issues in Pictorial Semiotics. Lecture One: The Quadrature of the Hermeneutic Circle", Course Overview at the Semiotics Institute, $<$ https:// semioticon.com/sio/courses/pictorial-semiotics/> [accessed July 9, 2016].

Sotelo Santos, Laura E.

2012 "Los códices mayas prehispánicos en la era digital", Revista Digital Universitaria, 13 (12), <http://www.revista.unam.mx/vol.13/num12/art115/> [accessed April 3, 2019].

Spinden, Herbert

1975 A Study of Maya Art: Its Subject Matter and Historical Development. New York: Dover Publications. 
Stuart, David S.

2011 The Order of Days: The Maya World and the Truth about 2012. New York: Three Rivers Press.

Taladoire, Eric and Jean-Pierre Courau

2005 Los mayas. Barcelona: Blume.

Taube, Karl A. and Bonnie Bade

1991 "An Appearance of Xiuhtecuhtli in the Dresden Venus Pages", Research Reports on Ancient Maya Writing, 35: 13-24. Washington, D.C.: Center for Maya Research.

Thompson, J. Eric. S.

1988 Un comentario al Códice de Dresde. Libro de jeroglifos mayas. México: Fondo de Cultura Económica.

Toscano, Salvador

1984 Arte precolombino de México y de la América Central, $4^{\mathrm{a}}$ edición. México: Universidad Nacional Autónoma de México, Instituto de Investigaciones Estéticas.

Van de Ven, Andrew and Marshal S. Poole

2005 "Alternative Approaches for Studying Organizational Change", Organization Studies, 26 (9): 1377-1404. Dol: https://doi.org/10.1177/0170840605056907.

Wells, Bryan

1991 "The Venus Table of the Dresden Codex and the Movements of the Planet Venus", The Journal of the Royal Astronomical Society of Canada, 85 (6), Whole No. 633: 291-315.

Whittaker, Gordon

1986 "The Mexican Names of Three Venus Gods in the Dresden Codex", Mexicon, 8 (3): 56-60.

Margarita Juárez Nájera. Mexicana. Licenciada en Ingeniería Química por el Instituto Politécnico Nacional de México, maestra en Ingeniería Ambiental por la Universidad Nacional Autónoma de México y doctora en Psicología Social por la Universidad Erasmo de Róterdam de los Países Bajos. Labora en la Universidad Autónoma Metropolitana, Unidad Azcapotzalco, México, Departamento de Energía. Su línea de investigación principal se centra en la aplicabilidad de la sustentabilidad en cualquier ámbito social, ambiental y económico. La precisión del calendario maya ha sido uno de sus intereses, por lo que ha pertenecido a varias sociedades astronómicas. Entre sus últimas publicaciones se encuentran "Introducing a Transdisciplinary Curriculum to Foster Student Citizenship: A Challenge 
beyond Curricula Reform", Sustainable Behaviour in Higher Education Institutions. An Exploratory Approach y Exploring Sustainable Behavior Structure in Higher Education. A Socio-Psychology Confirmatory Approach, las dos últimas con autora única.

mjn@azc.uam.mx

Mariana Castellanos. Mexicana-canadiense. Licenciada en Literatura Latinoamericana y Diplomada en Historía del Arte por la Universidad Iberoamericana, México; maestra en Museología por la Unviersidad de Montreal; maestra en Administración de Empresas Culturales por HEC-Montreal; candidata a doctora en Administración Pública por la École Nationale d'Aministration Publique, Montreal, Canadá. Entre sus líneas de investigación se encuentran las mutaciones en el sector cultural mundial. Su interés por la cultura mexicana la llevó a desempeñarse en la galería del Consulado de México en Montreal, donde ha co origanizado "La Fête des Morts", con el Centro de Historia de Montreal. Entre sus últimas publicaciones se encuentran "L'acte artistique face à l'écueil écologique" y "How Hypermodern and Accelerated Society is Challenging the Cultural Sector".

mariana.castellnosjuarez@enap.ca 